\title{
Positive Regulation of the Hrp Type III Secretion System in Pseudomonas syringae pv. phaseolicola
}

\author{
Inmaculada Ortiz-Martín, ${ }^{1}$ Richard Thwaites, ${ }^{2}$ Alberto P. Macho, ${ }^{1}$ John W. Mansfield, ${ }^{3}$ and \\ Carmen R. Beuzón' \\ ${ }^{1}$ Instituto de Hortofruticultura Subtropical y Mediterranea, Universidad de Málaga-Consejo Superior de Investigaciones \\ Científicas (IHSM-UMA-CSIC), Depto. Biología Celular, Genética y Fisiología, Campus de Teatinos, Málaga E-29071, \\ Spain; ${ }^{2}$ Food and Environment Research Agency, Sand Hutton, YO41 1LZ, York, U.K.; ${ }^{3}$ Faculty of Natural Science, \\ Division of Biology, Sir Alexander Fleming Bd. Imperial College London, South Kensington, SW7 2AZ, London
}

Submitted 26 August 2009. Accepted 12 January 2010.

Disease in compatible hosts and induction of the hypersensitive response in resistant plants by most plant-pathogenic bacteria require a functional type III secretion system (T3SS). Expression of T3SS genes responds to host and environmental factors and is induced within the plant. In Pseudomonas syringae, expression of the T3SS requires HrpL, which is transcriptionally upregulated by HrpR and HrpS. In some pathovars, expression of the hrpRS genes is upregulated by the GacA/S two-component system. Additionally, HrpA, the major component of the T3SS pilus, has also been linked to the regulation of the $h r p R S$ gene expression. Previous studies concerning regulation of hypersensitive response and pathogenesis/hypersensitive response conserved (hrp/hrc) gene expression have used mostly in vitro inducing conditions, different pathovars, and methodology. Here, we analyze the roles of $\mathrm{HrpL}$, GacA, and HrpA in the bean pathogen, using single, double, and triple mutants as well as strains ectopically expressing the regulators. We use real-time polymerase chain reaction analysis in vitro and in planta to quantify gene expression and competitive indices and other assays to assess bacterial fitness. Our results indicate that i) $\mathrm{HrpL}$ acts as a general virulence regulator that upregulates non-T3SS virulence determinants and downregulates flagellar function; ii) GacA modulates the expression of $h r p L$, and its contribution to virulence is entirely HrpL dependent; iii) there is a basal HrpL-independent expression of the T3SS genes in rich medium that is important for full activation of the system, maybe by keeping the system primed for rapid activation upon contact with the plant; and iv) HrpA upregulates expression of the T3SS genes and is essential to activate expression of the hrpZ operon upon contact with the plant.

Type III secretion systems (T3SSs) are complex and specialized machineries used by many Gram-negative bacteria to deliver proteins directly into the host cell cytosol. In plant pathogenic bacteria, the T3SS is required to cause disease in compatible hosts and to elicit the hypersensitive response (HR) in resistant hosts (Alfano and Collmer 1997). The structural components of the secretion apparatus are encoded within the

Corresponding author: C. R. Beuzón; Telephone: ++ 34-952-131959; Fax: ++ 34-952-132001; E-mail: cbl@uma.es

* The $\boldsymbol{e}$-Xtra logo stands for "electronic extra" and indicates that a supplementary table is available online. hypersensitive response and pathogenesis/hypersensitive response conserved ( $h r p / h r c)$ locus, which is organized into several operons (Arnold et al. 2001). Different host and environmental factors regulate the expression of the hrp genes in Pseudomonas syringae (Rahme et al. 1992; Xiao et al. 1992; Xiao et al. 2004). This regulation has been recently proposed to take place at three different levels, by i) environmental signals, ii) soluble plant signals, and iii) contact with the cell wall (Haapalainen et al. 2009).

HrpL is a member of the ECF family of alternative sigma factors that activates transcription of promoters carrying an "hrp box" consensus sequence, thus upregulating the expression of $\mathrm{hrp} / \mathrm{hrc}$ genes in $P$. syringae (Xiao and Hutcheson 1994; Xiao et al. 1994; Fouts et al. 2002). Expression of $h r p L$ is activated by HrpR and HrpS, two homologous DNA-binding proteins similar to the NtrC family regulators (Xiao et al. 1994). HrpR and HrpS form a heterodimer that binds the hrpL promoter and activate its transcription, which requires the RpoN alternative sigma factor (Hendrickson et al. 2000; Hutcheson et al. 2001). Although all HrpL-upregulated genes are also upregulated by HrpR/S, there are a considerable number of non-T3SS genes, including some transcriptional regulators, regulated by $\mathrm{HrpR} / \mathrm{S}$ in an HrpL-independent manner (Lan et al. 2006). HrpR and HrpS are expressed as a single operon (hrpRS operon) in P. syringae pv. syringae and $P$. syringae pv. tomato (Hutcheson et al. 2001). However, in $P$. syringae pv. phaseolicola, they have been reported as expressed from different promoters, with HrpR activating expression of the hrpS gene (Grimm et al. 1995; Schuster and Grimm 2000).

In $P$. syringae pv. tomato, although not in $P$. syringae pv. syringae, expression of the $h r p R S$ operon is modulated by the GacA/GacS two-component regulatory system (Chatterjee et al. 2003). This system is present in numerous bacteria, including several plant pathogens. GacS is a putative sensor kinase that, upon receiving a signal, would autophosphorylate and activate the response regulator GacA. Little is known about the nature of the signals perceived by GacS or the regulation of GacA production and function although, in $P$. syringae pathovars, GacA production seems to be activated by stress and growth phase (Chatterjee et al. 2003).

A mutation in $h r p A$, encoding the major component of the T3SS pilus necessary for secretion (Roine et al. 1997), has been shown to cause a reduction in the accumulation of structural components of the apparatus in P. syringae pv. tomato DC3000. This effect, as severe as the reduction found in a $h r p S$ mutant and detected in both inducing medium and within the plant, was reported to take place through HrpA upregulation of the expres- 
sion of the $h r p R S$ operon, because ectopic expression of this operon in the $h r p A$ mutant recovered wild-type levels of expression (Wei et al. 2000). A very recent report (Haapalainen et al. 2009) has shown that soluble plant cell signals induce the expression of $h r p / h r c$ genes and specifically upregulate the production of HrpA. Interestingly, they found that HrpA does not accumulate to high levels intracellularly, not even in a secretion-deficient $h r c C$ mutant strain, suggesting that some kind of feedback regulation could take place between secretion and production of HrpA, perhaps through degradation of intracellular HrpA.

Several studies have contributed to models for the regulation of the expression of the hrp/hrc genes in P. syringae. However, they have been carried out using mainly laboratory inducing conditions. Furthermore, the roles of the different components of this regulatory cascade have been addressed in different pathovars, providing a somewhat fragmentary picture further complicated by the fact that differences between the specific roles of some of the regulators in different pathovars have already been found. Thus, we have analyzed the role of these different regulators within the same pathovar, $P$. syringae pv. phaseolicola 1448a, using expression and virulence analyses within the host plant as well as other expression and functional in vitro assays. In this work, we analyze and revise the roles that HrpL, HrpA, and GacA have in the regulation of hrp/hrc gene expression and, ultimately, in the pathogenic process, by applying real-time polymerase chain reaction (PCR), competitive indices, and other pathogenicity assays to the analysis of

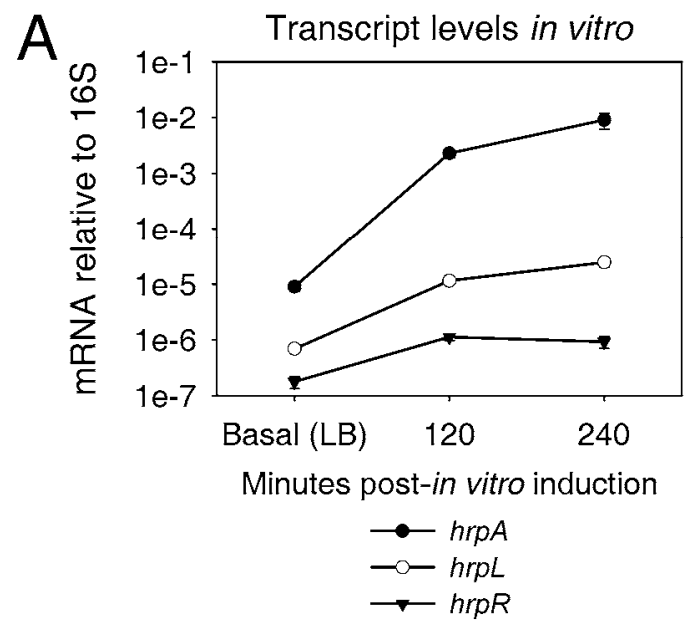

$\mathrm{B}$

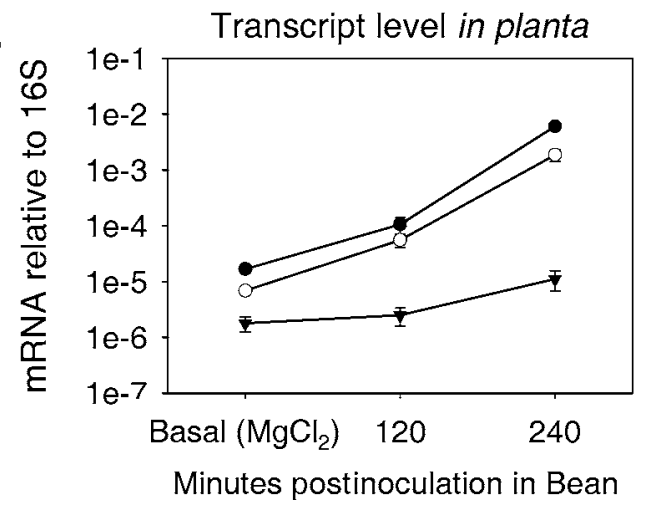

Fig. 1. Expression of $h r p A$ (black circles), $h r p L$ (white circles), and $h r p R$ (black triangles) genes in wild-type strain, at 120 or 240 min after transfer to minimal medium (minutes postinoculation [mpi]) into leaves of the susceptible bean cv. Canadian Wonder. Basal measures correspond to transcripts levels in Luria-Bertani medium $\mathbf{A}$, prior to induction and $\mathbf{B}$, at 5 mpi. Results shown are obtained from triplicate analyses. Error bars represent the standard deviation. single- and double-mutant strains as well as strains ectopically expressing the regulators at different levels. A similar approach has been used to analyze the role of negative regulators of this system, and the results obtained are presented in the accompanying report (Ortiz-Martín et al. 2010).

Our results indicate that i) HrpL acts as a general virulence regulator that, in addition to its role activating the expression of the $h r p / h r c$ genes, upregulates expression of T3SS-independent virulence factors and downregulates the flagellar function; ii) GacA modulates expression of $h r p L$, probably indirectly through regulation of $h r p R$ expression, and its contribution to virulence is entirely $\mathrm{HrpL}$ dependent; iii) there is a basal HrpL-independent expression of the $h r p / h r c$ genes in rich medium important for full activation that could act to guarantee a system primed for quick activation upon contact with the plant apoplast; and iv) HrpA upregulates the expression of the $h r p / h r c$ genes through a positive feedback mechanism that is essential for the expression of the hrpZ operon.

\section{RESULTS AND DISCUSSION}

\section{Real-time PCR expression analysis of $\mathrm{hrp} / \mathrm{hrc}$ genes in laboratory media and in planta.}

Different studies have used a variety of experimental settings and methodology to analyze the expression of $h r p / h r c$ genes in plant-pathogenic bacteria. We chose to follow the methodology developed by Thwaites and collaborators (2004) to quantify RNA levels, which offers a high level of sensibility and specificity (Wang and Brown 1999; Johnson et al. 2000) and includes the analysis of $h r p / h r c$ gene expression both in vitro and in planta. We selected $h r p R, h r p L$, and $h r p A$ for analysis as representatives of each level of the $h r p$ regulatory circuit. The first two are the principal activators of $h r p / h r c$ gene expression and show very different expression dynamics, whereas the hrpA gene is a highly expressed representative of HrpL-regulated genes (Thwaites et al. 2004).

The dynamics of expression of these genes in the wild-type strain reflected those previously described (Thwaites et al. 2004), with a peak of expression by $240 \mathrm{~min}$ after transfer to minimal medium (minutes postinoculation [mpi]) in the case of $h r p L$ and $h r p A$ and $120 \mathrm{mpi}$ in the case of $h r p R$ (Fig. 1A). Maximal induction levels ranged between 10- and 1,300-fold of that measured in rich medium, with induction of $h r p A$ being the highest of the three genes and induction of the regulatory $h r p R$ gene the lowest. In keeping with most recent reports (Thwaites et al. 2004), our assays showed a clear 10-fold induction of the expression of $h r p R$ after incubation in minimal medium.

In planta, expression was five- to 50-fold higher than maximal levels in minimal medium (Fig. 1B), with hrpL expression showing the highest increase. Maximal expression in planta was reached by 240 mpi into bean leaves. Although maximal levels of induction for all three genes were higher in planta than in both noninducing and inducing media, this difference was smaller for $h r p R$ (10-fold increase compared with minimal media and 55-fold compared with Luria-Bertani [LB] medium).

Quantifying the impact of HrpL on $h r p / h r c$ gene expression.

In rich medium (LB), expression of the $h r p / h r c$ genes in a strain carrying a deletion of the $h r p L$ gene (IOM7, $\Delta h r p L$ ) (Table 1) was no different from that of the wild type (Fig. 2A). These results were expected considering that $h r p / h r c$ gene expression is repressed in LB medium (Huynh et al. 1989; Rahme et al. 1992; Xiao et al. 1992). However, results obtained in a related study, supports the notion of a basal level of expression of $h r p / h r c$ operons taking place in LB medium (Ortiz-Martín et al. 2010). That study shows that deletion of the gene encoding one or both the HrpV negative regulator 
(Preston et al. 1998) or the neighboring hrpT gene results in a clear increase in $h r p / h r c$ gene expression in LB medium. For $\mathrm{HrpV}$ and HrpT to downregulate $h r p / h r c$ expression in LB, the $h r p C$ operon that includes the $h r p T$ and the $h r p V$ genes must be expressed in this medium, even if at a very low level. Thus, we expected to find a difference between the wild-type strain and the $h r p L$ mutant in $h r p / h r c$ expression or, at least, in the expression of the $h r p C$ operon in rich medium. However, when

Table 1. Pseudomonas syringae strains used in this study

\begin{tabular}{|c|c|c|}
\hline Strain & Description $^{\text {a }}$ & Reference \\
\hline IOM3 & $\Delta h r c C\left(\mathrm{Km}^{\mathrm{r}}\right)$ & Ortiz-Martin et al. 2006 \\
\hline IOM7 & $\Delta h r p L\left(\mathrm{Km}^{\mathrm{r}}\right)$ & Ortiz-Martin et al. 2006 \\
\hline IOM9 & $\Delta h r p V h r p T-01$, carrying a deletion that includes the entire ORF of $h r p V$ and the last 9 nucleotides of $h r p T\left(\mathrm{Km}^{\mathrm{r}}\right)$ & Ortiz-Martin et al. 2010 \\
\hline IOM37 & $\Delta h r p L\left(\mathrm{Cm}^{\mathrm{r}}\right) \Delta h r c C\left(\mathrm{Km}^{\mathrm{r}}\right)$ & This work \\
\hline IOM49 & $\Delta h r p A\left(\mathrm{Km}^{\mathrm{r}}\right)$ & This work \\
\hline IOM50 & $\triangle \operatorname{gac} A\left(\mathrm{Km}^{\mathrm{r}}\right)$ & This work \\
\hline IOM50-F & $\triangle \operatorname{gacA}\left(\mathrm{Km}^{\mathrm{s}}\right)$ & This work \\
\hline IOM61 & $\Delta h r p R S\left(\mathrm{Km}^{\mathrm{r}}\right)$ & This work \\
\hline IOM61-F & $\Delta h r p R S\left(\mathrm{Km}^{\mathrm{s}}\right)$ & This work \\
\hline IOM72 & $\Delta g a c A \Delta h r p L\left(\mathrm{Km}^{\mathrm{r}}\right)$ & This work \\
\hline IOM73 & $\Delta h r p R S \Delta h r p L\left(\mathrm{Km}^{\mathrm{r}}\right)$ & This work \\
\hline
\end{tabular}

${ }^{\mathrm{a}} \mathrm{Km}^{\mathrm{r}}, \mathrm{Cm}^{\mathrm{r}}$, and $\mathrm{Amp}^{\mathrm{r}}$ indicate resistance to kanamycin, chloramphenicol, and ampicillin, respectively; ORF = open reading frame; and $\mathrm{Km}^{\mathrm{s}}$ indicates sensitivity to kanamycin.

A

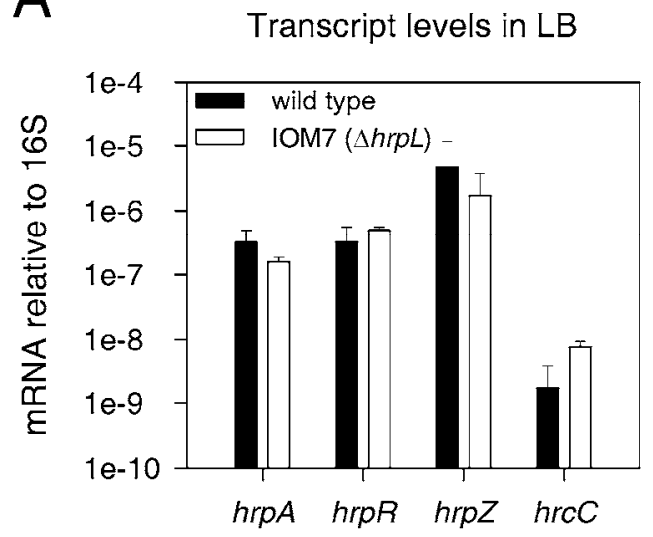

C

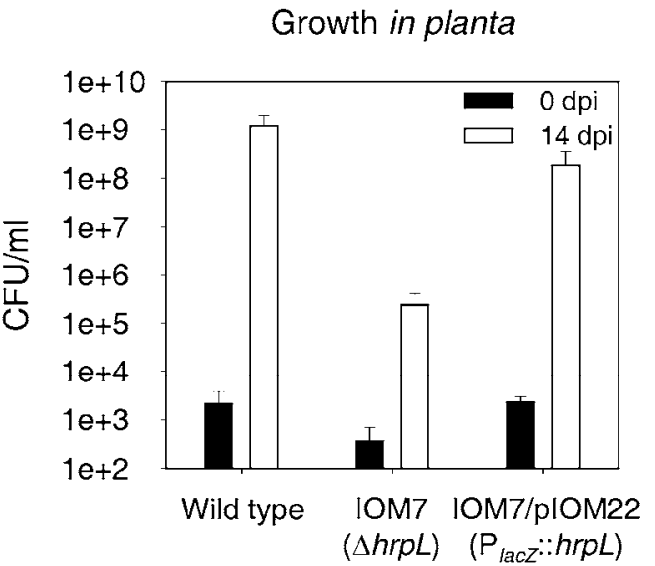

B

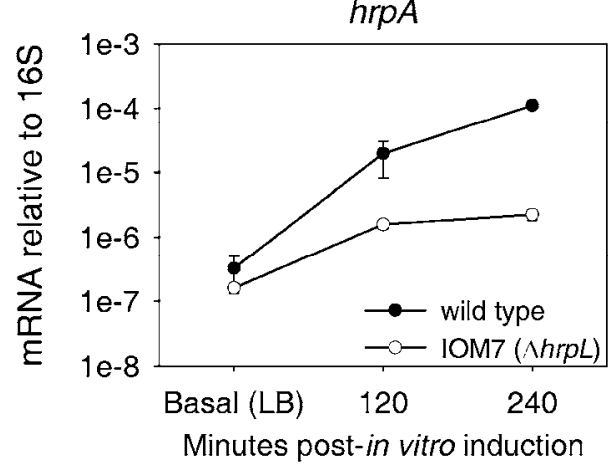

hrpZ
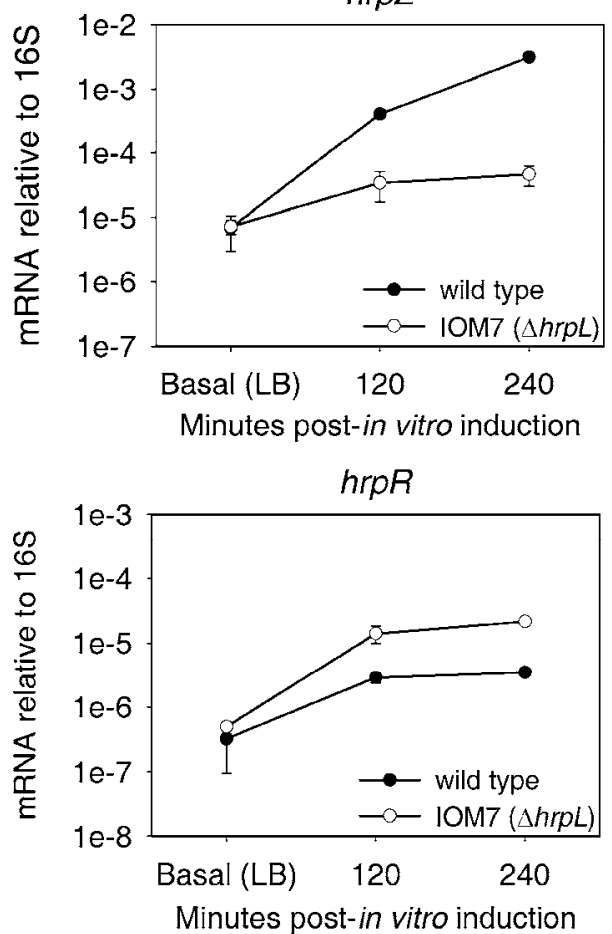

Fig. 2. Expression levels of hypersensitive response and pathogenesis/hypersensitive response conserved ( $h r p / h r c)$ genes in wild-type and $\Delta h r p L$ mutant strains. A, Number of transcripts relative to $16 \mathrm{~S}$ of the wild type (black rectangles) compared with $\Delta h r p L$ mutant (white rectangles) in Luria-Bertani (LB) medium, for the $h r p A, h r p R, h r p Z$, and $h r c C$ genes. B, Induction of $h r p A, h r p Z$, and $h r p R$ genes in the wild type (black circles) and $\Delta h r p L$ mutant (white circles) at 120 or 240 min after transfer to minimal medium (mpi). Basal measures correspond to transcripts levels in LB medium prior to induction. Results shown are obtained from

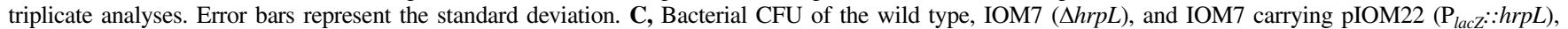
immediately after inoculation into bean leaves ( 0 days postinoculation [dpi]) (black rectangles) and by 14 dpi (white rectangles). 
expression of $h r c C$, which lies immediately upstream of $h r p T$ and $h r p V$ within this operon, was analyzed, no significant differences were found between the wild-type and the $\Delta h r p L$ mutant strain in rich medium (Fig. 2A). Therefore, basal expression of $h r p / h r c$ genes in LB is HrpL independent. A basal level of expression under repressing conditions (regardless of its HrpL dependency), allowing HrpV/HrpT-mediated downregulation to take place, could keep the system primed for rapid activation upon meeting inducing conditions.

Interestingly, when expression of these genes was analyzed under laboratory inducing conditions, a small but significant induction of the expression of $h r p A$ and $h r p Z$ (14- and sixfold, respectively), was still detectable in the $\triangle h r p L$ mutant strain (Fig. 2B). Indeed, the level of induction detected for these genes in the $\Delta h r p L$ mutant was comparable with the level of induction found for the $h r p R$ gene in the wild-type strain (Fig. 2B). These results indicate that the HrpL-independent expression component of the hrp/hrc genes in LB can be activated upon transfer to inducing medium, showing an increase of five- to 50-fold, depending on the gene, by 240 mpi (Fig. 2B).

Thwaites and collaborators (2004) reported that expression of the hrpRS operon in P. syringae pv. phaseolicola 1448a was induced in minimal medium, and that the level of this induction was dependent on HrpL. Ferreira and colleagues (2006) reported that expression of the hrpRS operon in minimal medium was instead downregulated by HrpL. Our results show a 10-fold increase in $h r p R$ expression in the wild-type strain by $240 \mathrm{mpi}$, supporting the notion of $h r p R S$ being environmentally regulated (Fig. 2B). By $240 \mathrm{mpi}, h r p R$ expression in the $\Delta h r p L$ mutant was 10 -fold higher than in the wild type (Fig. 2B), supporting a role for HrpL in downregulating the expression of $h r p R$, in keeping with the results described by Ferreira and associates (2006).

\section{Ectopic expression of HrpL and its effect on $\mathbf{h r p} / \mathrm{hrc}$ gene expression.}

We generated a plasmid expressing HrpL from the mediumto low-expression lacZ promoter (pIOM22, $\mathrm{P}_{\text {lac } Z}:$ :hrpL) (Table 2 ). The plasmid was capable of complementing the failure to induce HR in tobacco leaves, as well as bacterial growth and symptom induction in bean leaves, of the $\Delta h r p L$ mutant strain (IOM7) (Fig. 2C and data not shown). Analysis of hrpL transcript levels in the wild-type strain carrying the plasmid showed that pIOM22 $\left(\mathrm{P}_{l a c z}:: h r p L\right)$ caused an increase of over a 1,000 fold more $h r p L$ transcripts than the wild type in LB (Fig. 3A).
As expected, although this strain accumulates higher levels of $h r p L$ in LB, its rate of induction in minimal medium was slower because only the chromosomally located gene is environmentally regulated (Fig. 3A). Expression of $h r p L$ from the $\mathrm{P}_{\text {lac }}$ promoter (pIOM22) caused a small increase in the expression of $h r p A$, hrcC, and $h r p Z$ in LB (5.8-, 9.7-, and 9.3-fold, respectively) (Fig. 3B). However, the level of expression of these genes in LB in the strain carrying pIOM22 was considerably lower than maximal levels reached in the wild-type strain after induction (240 mpi) (Fig. 3C), indicating that overexpression of $h r p L$ by more than a 1,000-fold does not fully activate hrp/hrc gene expression, and either additional repressing factors must still be in place or additional activating factors missing. The expression of the $h r p / h r c$ genes displayed similar induction rates in minimal medium in the wild-type strain carrying pIOM22 and in the wild type; therefore, because expression levels before induction were higher in the strain carrying the plasmid, higher levels of all the genes analyzed (three- to 11fold) were reached by $240 \mathrm{mpi}$ (Fig. 3C). Induction in both strains is fully consistent with the induction of expression of the chromosomically encoded HrpL. These results further support the idea that overexpression of HrpL does not fully activate $h r p / h r c$ gene expression. Overexpression of $\mathrm{HrpL}$ has been previously reported to cause constitutive activation of the hrp/hrc gene expression (Xiao et al. 1994); however, these results were obtained by analyzing the expression of plasmidencoded lacZ gene fusions driven from several hrp/hrc promoters in Escherichia coli, where none of the additional regulatory elements were present.

To our surprise, we also found an increase in the expression of $h r p R$ in the wild-type strain carrying pIOM22 in both LB and inducing medium, which was comparable with the increase found in the expression of $h r p A$ (Fig. 3B and C). This result would suggest an HrpL-mediated upregulation of $h r p R$ expression and, therefore, would be contradictory to the results obtained with the $\Delta h r p L$ mutant by our team and others (Ferreira et al. 2006) and support those obtained by Thwaites and collaborators (2004). In any case, it is unclear how HrpL would participate in the regulation of the expression of the $h r p R$ gene, because no potential hrp box can be found upstream of the $h r p R$ promoter (Ferreira et al. 2006; Vencato et al. 2006), suggesting additional factors involved and an indirect effect in a more complex scenario, which could explain the difficulties found by our and other teams to reach a clear conclusion on this issue.

Table 2. Plasmids used in this study

\begin{tabular}{|c|c|c|c|}
\hline Plasmids & Description & Resistance & Reference \\
\hline pDN18-N-hrpA $A_{P t o}$ & Contains the wild-type hrpA gene from Pseudomonas syringae pv. tomato DC3000 & Tet $^{\mathrm{r}}$ & Taira et al. 1999 \\
\hline pDN18-N-hrpA $A_{P p h}$ & Contains the wild-type $h r p A$ gene from $P$. syringae pv. phaseolicola $1448 \mathrm{a}$ & Tet $^{\mathrm{r}}$ & This work \\
\hline pPPY430 & pLAFR3-based genomic clone for race 4 & $\mathrm{Tet}^{\mathrm{r}}$ & Mansfield et al. 1994 \\
\hline pIOM21 & pBBR1-MCS-4 derivative, contains the $h r c C$ gene expressed from the $l a c Z$ promoter & $A m p^{r}$ & This work \\
\hline pIOM22 & pBBR1-MCS-4 derivative, contains the $h r p L$ gene expressed from the $l a c Z$ promoter & $A m p^{r}$ & This work \\
\hline pIOM26 & pBBR1-MCS-4 derivative, contains the hrpA gene expressed from the lac $Z$ promoter & $A m p^{r}$ & This work \\
\hline pIOM33 & pAMEX derivative, contains the $h r p A$ gene expressed from the $n p t I I$ promoter & $A m p^{r}, K^{r}$ & This work \\
\hline pIOM28 & pBBR1-MCS-4 derivative, contains the $h r p A Z$ gene expressed from the $l a c Z$ promoter & $\mathrm{Amp}^{\mathrm{r}}$ & This work \\
\hline pIOM50 & pBBR1-MCS- 4 derivative, contains the $h r p R S A$ gene expressed from the lacZ promoter & $\mathrm{Amp}^{\mathrm{r}}$ & This work \\
\hline pIOM51 & pAMEX derivative, contains the hrpRSA gene expressed from the nptII promoter & $\mathrm{Amp}^{\mathrm{r}}, \mathrm{Km}^{\mathrm{r}}$ & This work \\
\hline pIOM100 & pAMEX derivative, contains the gacA gene expressed from the $n p t I I$ promoter & $\mathrm{Amp}^{\mathrm{r}}, \mathrm{Km}^{\mathrm{r}}$ & This work \\
\hline pIOM9 & pKAS32 derivative, contains $\Delta h r c C:: a p h A$ & $\mathrm{Amp}^{\mathrm{r}}, \mathrm{Km}^{\mathrm{r}}$ & Ortiz-Martín et al. 2006 \\
\hline pIOM67 & $\begin{array}{l}\text { pGEM-T derivative, contains approximately } 0.5 \mathrm{~kb} \text { on each side of the hrpA gene } \\
\text { interrupted by the kanamycin resistance gene nptII. }\end{array}$ & $A m p^{r}, K^{r}$ & This work \\
\hline pIOM68 & $\begin{array}{l}\text { pGEM-T derivative, contains approximately } 0.5 \mathrm{~kb} \text { on each side of the gacA gene } \\
\text { interrupted by the kanamycin resistance gene } n p t I I\end{array}$ & $A m p^{r}, K m^{r}$ & This work \\
\hline pIOM82 & $\begin{array}{l}\text { pGEM-T derivative, contains approximately } 1 \mathrm{~kb} \text { upstream of the } h r p R \text { gene and } \\
\text { approximately } 0.5 \text { downstream of the } h r p S \text { gene interrupted by the kanamycin resistance } \\
\text { gene } n p t I I\end{array}$ & $\mathrm{Amp}^{\mathrm{r}}, \mathrm{Km}^{\mathrm{r}}$ & This work \\
\hline
\end{tabular}

${ }^{\mathrm{a}} \mathrm{Km}^{\mathrm{r}}, \mathrm{Sm}^{\mathrm{r}}, \mathrm{Tet}^{\mathrm{r}}$, and $\mathrm{Amp}^{\mathrm{r}}$ indicate resistance to kanamycin, streptomycin, tetracycline, and ampicillin, respectively. 
Analyzing HrpL-dependent expression within the plant.

Induction of the $h r p / h r c$ gene expression in laboratory medium is a simple method for expression analysis; however, information on how the T3SS is regulated in planta may be missed (Haapalainen et al. 2009). Therefore, we analyzed expression of the $h r p / h r c$ genes in wild-type and $\Delta h r p L$ mutant strains following inoculation into bean leaves. As expected, expression of $h r p A, h r p Z$, and $h r c C$ was approximately 100 -fold lower in the $h r p L$ mutant strain than in the wild type by 240 mpi (Fig. 4). Interestingly, a clear HrpL-independent induction of the expression could be detected for the highly expressed $h r p Z$ gene (15-fold induction by $240 \mathrm{mpi}$ ). It is clear that the T3SS requires HrpL for its function; however, such a basal HrpL-independent in planta expression of some or all the hrp/hrc operons could be an indication of the existence of additional levels of regulation to those already described.

The analysis in planta of the expression of the $h r p R$ gene in the $h r p L$ mutant strain revealed levels similar to those detected in the wild-type strain by either 120 or $240 \mathrm{mpi}$, although its expression by $5 \mathrm{mpi}$ was slightly higher (1.8-fold) in the $\Delta h r p L$ mutant (Fig. 4). In keeping with previous reports, our results confirm that expression of $h r p R$ in $P$. syringae pv. phaseolicola is activated within the plant as well as in minimal medium. However, whether HrpL carries out this upregulation or could act as part of a negative feedback mechanism downregulating its expression cannot be established. All that we can conclude is that any regulatory effect that HrpL may be having on the expression of $h r p R S$ in planta must certainly be very subtle, most likely carried out indirectly, and involve other factors.

\section{HrpL upregulates expression}

of an additional T3SS-independent virulence factor.

To determine whether any non-T3SS, HrpL-regulated gene is required for virulence in $P$. syringae pv. phaseolicola, we analyzed growth of a $\Delta h r p L \Delta h r c C$ double-mutant strain (IOM37) (Table 1) within the plant, in mixed infection with the
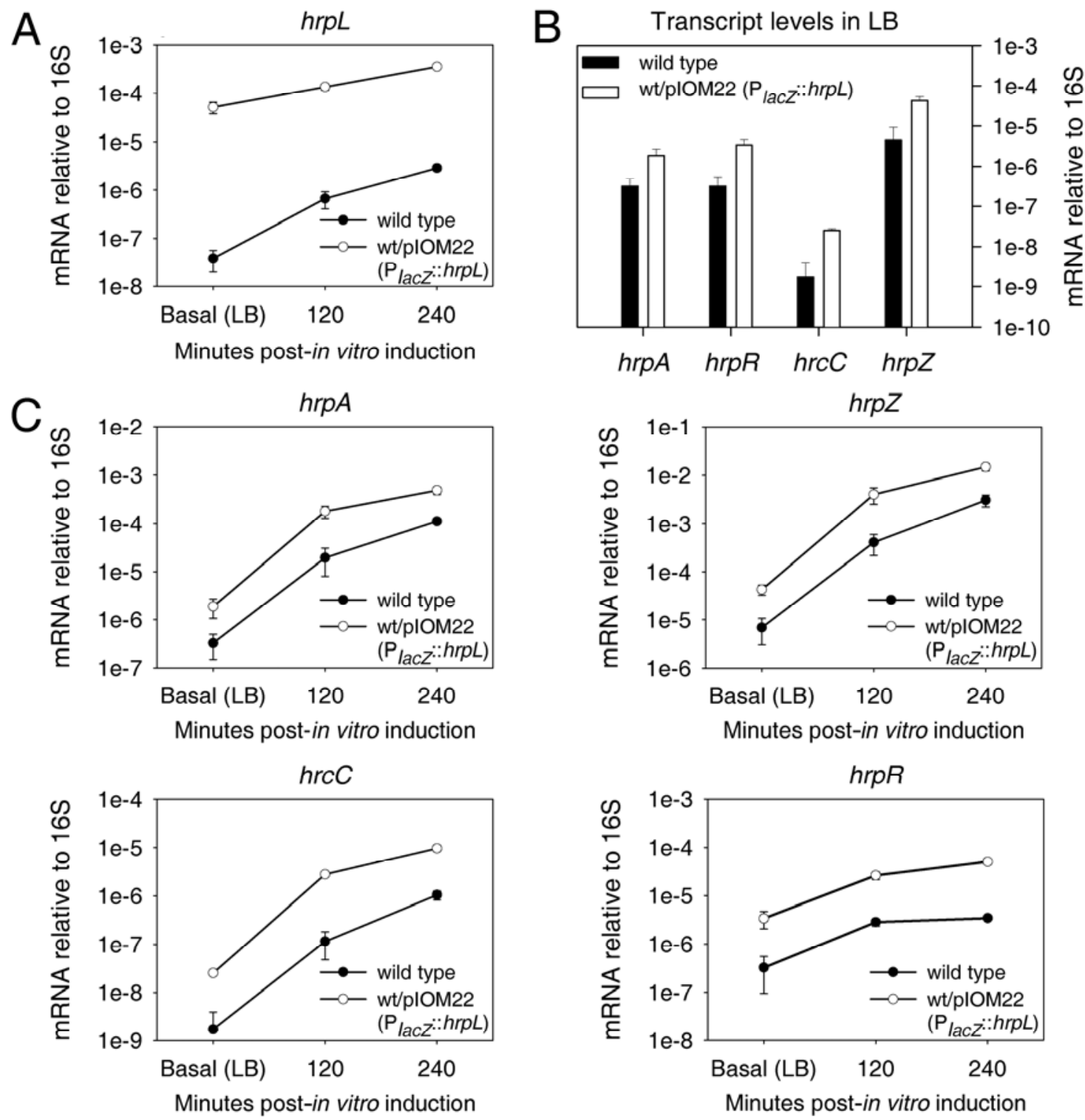

Fig. 3. Ectopic expression of HrpL. A, Expression of hrpL gene in wild-type strain (black circles) and the wild type expressing HrpL under the control of a lacZ promoter (white circles) at 120 and 240 min after transfer to minimal medium (minutes postinoculation [mpi]). B, Number of transcripts relative to $16 \mathrm{~S}$ of the wild type (black rectangles) compared with the wild type expressing HrpL from a lacZ promoter (white rectangles) in Luria-Bertani (LB) medium for $h r p A, h r p R, h r c C$, and $h r p Z$ genes. C, Induction of $h r p A, h r p Z, h r c C$, and $h r p R$ genes in the wild type (black circles) and the wild type expressing HrpL under the control of a lacZ promoter (white circles) at 120 and 240 mpi. Basal measures correspond to transcripts levels in LB medium prior to induction. Results shown are obtained from triplicate analyses. Error bars represent the standard deviation. 
isogenic single $\Delta h r c C$ mutant strain (IOM3) (Table 1). Because T3SS secretion requires a functional $\mathrm{HrcC}$, if the T3SS genes were the only members of the HrpL regulon required for virulence in $P$. syringae pv. phaseolicola, a $\Delta h r c C$ mutant strain would be as attenuated as the single $\Delta h r p L$ or the $\Delta h r p L \Delta h r c C$ double mutant because, in all three strains, the T3SS function would be equally impaired. To analyze this possibility, we used a modification of the competitive index (CI) assays: the cancelled-out index (COI). The CI of a given strain co-inoculated in equal amounts with the wild type is defined as the mutantto-wild type ratio in the output sample, divided by the mutantto-wild type ratio within the initial mixed inoculum (Freter et al. 1981; Taylor et al. 1987). We have previously shown that CI is a precise and sensitive measure of bacterial growth within the plant for $P$. syringae, when using inoculation doses previously established to avoid interference between co-inoculated strains (Macho et al. 2007). The COI is carried out using the same methodology as CI assays but compares growth between a double mutant and an isogenic single-mutant strain. COI assays have been previously used to establish functional relationships between virulence genes in Salmonella enterica (Beuzón and Holden 2001; Beuzón et al. 2001). We found that the COI of a $\Delta h r p L \Delta h r c C$ double mutant in mixed infection with the $\Delta h r c C$ mutant was significantly lower than 1 , therefore indicating that a mutation in the $h r p L$ gene causes a small but significant $h r c C$-independent attenuation of growth (Fig. 5A). Furthermore, the results obtained in CI assays for each of the single mutants showed that the attenuation caused by the $\Delta h r p L$ mutation is significantly higher than that caused by the $\Delta h r c C$ mutation (Fig. 5A). In summary, although the main virulence determinant of the $P$. syringae pv. phaseolicola $\mathrm{HrpL}$ regulon is the T3SS, this regulon must also include non-T3SS related virulence determinants. Whether these are previously unidentified virulence determinants or already reported ones for which HrpL regulation has not been yet determined remains to be investigated. This is the first evidence for non-T3SS virulence determinants as part of the $P$. syringae pv. phaseolicola HrpL regulon; however, in related pathovars, non-T3SS virulence determinants, such as the $i a a L$ and $s y r E$ genes, as well as the biosynthetic genes for the phytotoxin coronatine in $P$. syringae pv. tomato (Fouts et al. 2002; Peñaloza-Vazquez et al. 2000), have already been shown to belong to this regulon.

We also carried out COI analysis to establish the relative roles of HrpR/S and HrpL in the $P$. syringae pv. phaseolicola virulence process. This was based on the results obtained by Lan and colleagues (2006) using microarrays, which showed that, although the genes belonging to the HrpL regulon are also part of the HrpR/S regulon, the HrpL regulon represents only one branch of the HrpR regulon, which also includes HrpL-independent genes. The attenuation of a strain carrying a $\triangle h r p R S$ deletion (IOM61) (Table 1), as established by CI assays, was found to be significantly smaller (close to 10-fold) than that of a $\Delta h r p L$ (IOM7) (Fig. 5A). Furthermore, the COI of a strain carrying the single $\Delta h r p L$ (IOM7) in a mixed infection with a strain carrying deletions in all three regulators $(\triangle h r p R S$ and $\Delta h r p L$, IOM73) (Table 1) showed, to our surprise, that the single mutant strain was, in fact, more attenuated in growth within the plant than the triple mutant strain (Fig. 5A). In keeping with this result, the reciprocal COI of the triple mutant strain (IOM73), in mixed infection with the strain carrying the $\Delta h r p R S$ deletion (IOM61), showed that both strains were equally attenuated within the plant, because the COI was not significantly different from 1 (Fig. 5A). These results show that deletion of the hrpRS in a strain carrying a $\Delta h r p L$ deletion actually promotes its growth. Interestingly, Lan and colleagues (2006) showed that the HrpL-independent part of the HrpR/S regulon includes a set of housekeeping genes that are downregulated by this two-component system. HrpR/S-mediated, HrpL-independent repression of
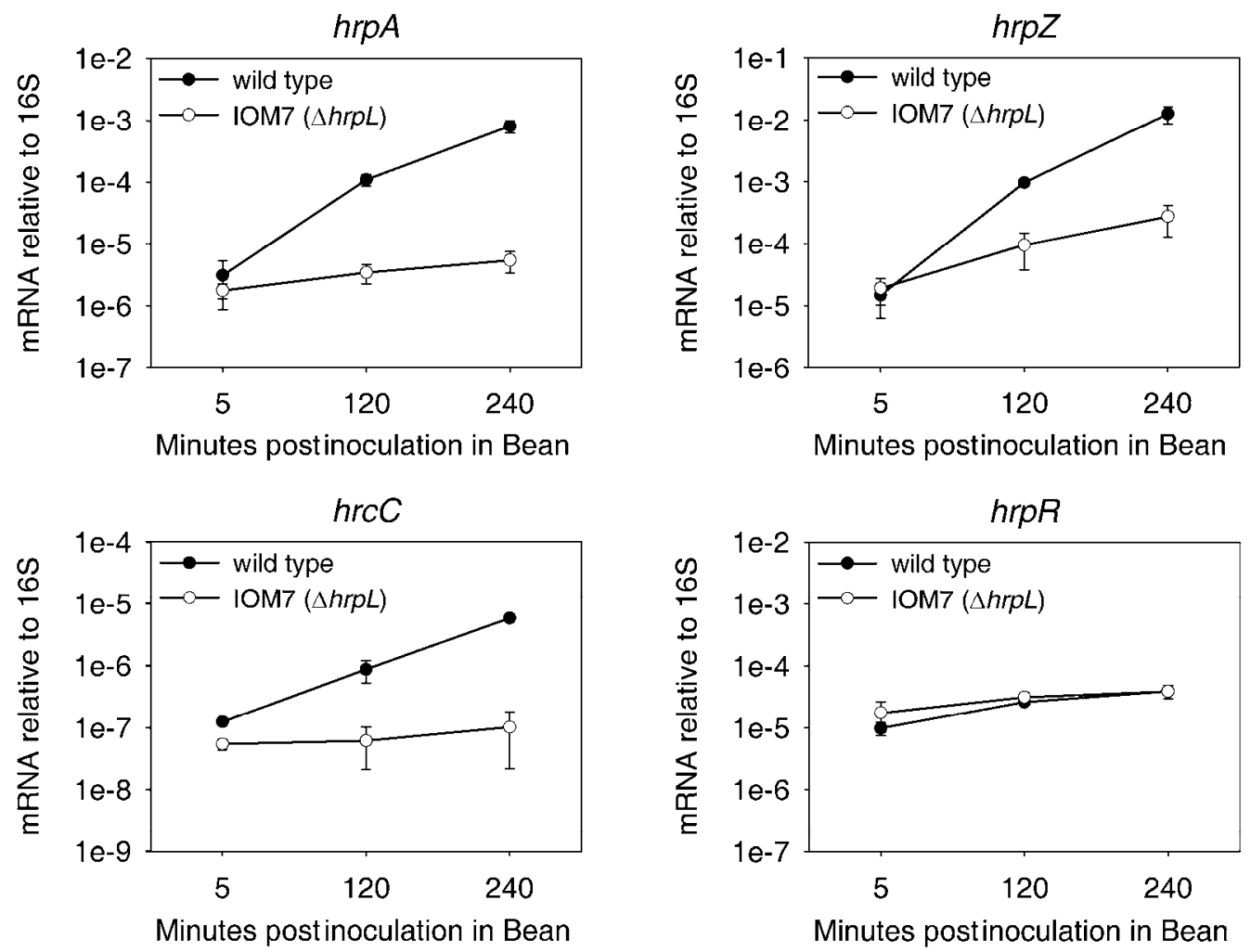

Fig. 4. Expression of $h r p A, h r p Z, h r c C$, and $h r p R$ genes in wild-type (black circles) and IOM7 ( $\Delta h r p L)$ (white circles) strains at 120 and 240 min postinoculation (mpi) into leaves of the susceptible bean cv. Canadian Wonder. Basal measures correspond to transcripts levels 5 mpi. Results shown are obtained from triplicate analyses. Error bars represent the standard deviation. 
housekeeping genes may be a way for bacteria to divert resources for the virulence process although, in the absence of a functional T3SS (i.e., a $\Delta h r p L$ mutant), this repression could further reduce its fitness. In such a scenario, lifting repression of housekeeping genes by deleting the $h r p R S$ operon in a $\Delta h r p L$ mutant could improve growth, and its deletion in a wild-type strain would cause a smaller growth defect than single deletion of the $\Delta h r p L$ gene, in keeping with our results.

\section{HrpL downregulates the flagellar function.}

Lan and colleagues (2006) reported that they found higher levels of expression in genes related to the flagellar system in
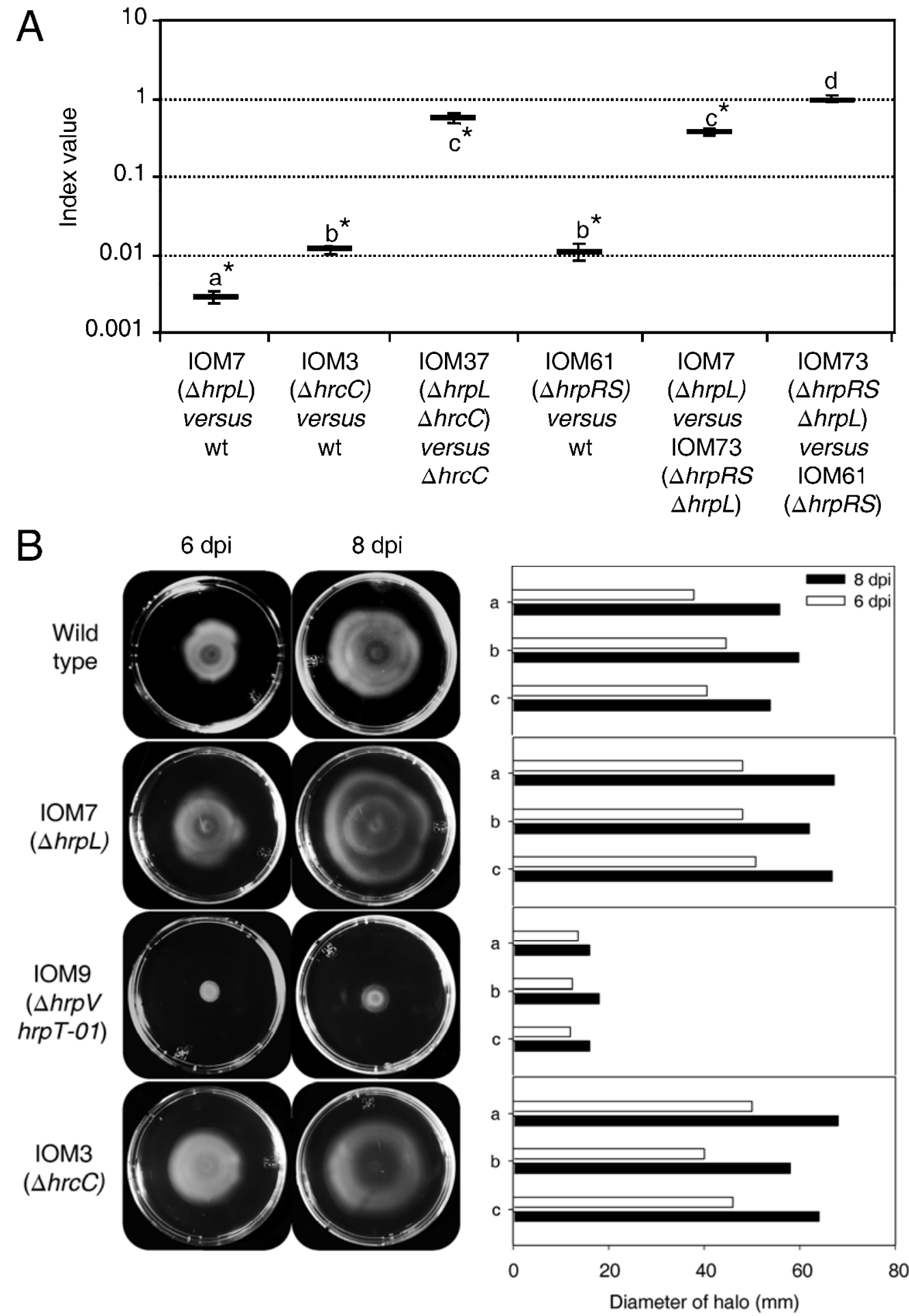

Fig. 5. A, Competitive indices (CI) of IOM7 ( $\Delta h r p L)$, IOM3 $(\Delta h r c C)$, and IOM61 ( $\Delta h r p R S)$ growing in a mixed infection with the wild type (wt) are shown, as well as cancelled-out indices (COIs) of IOM37 ( $\Delta h r p L \Delta h r c C$ ) versus IOM3 ( $\Delta h r c C$ ), IOM7 ( $\Delta h r p L)$ versus IOM73 ( $\Delta h r p R S \Delta h r p L)$, and IOM73 $(\triangle h r p R S \Delta h r p L)$ versus IOM61 $(\triangle h r p R S)$. Asterisks indicate indices significantly different from 1 and different letters indicate indices significantly different from each other, as established using Student's $t$ test $(P<0.05)$. Each CI value represents the mean from three independent experiments. Error bars represent the standard error. B, Motility test 6 and 8 days postinoculation (dpi) on $h r p$-inducing medium (HIM) of wt, IOM7 ( $\Delta h r p L$ ), IOM9 ( $\Delta h r p V h r p T-01$ ), and IOM3 $(\Delta h r c C)$ strains. Left panels show images of representative motility halos for each of the strains at 6 and 8 dpi. Right panel shows the diameters of the motility halos determined for each strain at these two time points, in three independent experiments (a, b, and c). 
$P$. syringae pv. tomato in the absence of $\mathrm{HrpR} / \mathrm{S}$. Suppression of the expression of the flagella after entry into the plant apoplast is probably beneficial for the bacteria because flagellin is a known pathogen-associated molecular pattern that triggers host defense responses (Zipfel et al. 2004). Interestingly, a previous study established that the flagellar system is downregulated by HrpL in Erwinia amylovora (Cesbron et al. 2006). To determine whether HrpL could also downregulate the flagellar system in P. syringae pv. phaseolicola, we compared the flagellar function of several strains by using motility assays and conditions described by Cesbron and colleagues (2006). We found that motility was greatly enhanced in the $\Delta h r p L$ mutant strain, for which a bigger motility could be seen by 6 days postinoculation (dpi) (Fig. 5B). Furthermore, strain IOM9 ( $\Delta$ hrpV hrpT-01) (Table 1), which causes a drastic increase on the expression of the $h r p / h r c$ genes (Ortiz-Martín et al. 2010), showed severely reduced motility in these assays, with only a very small motility halo detectable by $8 \mathrm{dpi}$ (Fig. 5B). These results indicate that HrpL downregulates the flagellar function in $P$. syringae pv. phaseolicola in a manner similar to that shown for E. amylovora by Cesbron and colleagues (2006). These results differ from the microarray results reported by Lan and colleagues (2006) for DC3000, which showed HrpLindependent HrpR-mediated downregulation of the flagellar genes. This indicates that the differences could reflect differences in the mechanisms of downregulation of flagellar function between $P$. syringae pv. phaseolicola 1448 a and $P$. syringae pv. tomato DC3000. However, an alternative explanation could be that, although the impact on motility of a deletion of $h r p L$ is considerable, the impact on the expression of the individual genes involved may be subtle and could have been missed by the microarray analysis.

Interestingly, a $\Delta h r c C$ mutant (IOM3) (Table 1) which lacks an essential component of the T3SS (Cornelis and Van Gijsegem 2000; Macho et al. 2007) showed a trend for a larger motility halo by 6 and 8 dpi (Fig. 5B). These results suggest that the function or assembly of the secretion apparatus could somehow participate in a feedback regulation affecting the activity of HrpL and, thus, the flagellar function. Such a mechanism is proposed in the accompanying report (Ortiz-Martín et al. 2010).

\section{Analyzing the impact of GacA in $h r p / h r c$ gene expression.}

We analyzed the expression of $h r p R$ and $h r p L$ in a $P$. syringae pv. phaseolicola 1448a derivative carrying a deletion of the gacA open reading frame (ORF) (strain IOM50) (Table 1). Expression of these two genes was not significantly increased in IOM50 growing in rich medium compared with the wild type (Fig. 6A, black rectangles). However, a significant reduction on the expression of these genes compared with the wild type could be detected in the mutant after growth in acidic minimal medium (Fig. 6A, white rectangles). Interestingly, the requirement of GacA for full expression of the hrp/hrc genes could be observed in acidic minimal medium, when transfer to minimal medium was carried out using exponentially growing bacteria (Fig. 6A) but not in our usual inducing conditions (Fig. 6B). Although our results suggest that GacA could also have a role in regulating $h r p / h r c$ gene expression in $P$. syringae pv. phaseolicola, possibly through regulation of $h r p R$ expression, its effect is not as clear as that reported for $P$. syringae pv. tomato (Chatterjee et al. 2003).

To determine the role of GacA in P. syringae pv. phaseolicola pathogenicity, we tested growth by CI of IOM50 in mixed infection with the wild-type strain. The CI obtained for IOM50 was significantly different from 1 (CI $=0.4087 \pm 0.0272$ ), indicating that the mutation of this gene also affects growth in P. syringae pv. phaseolicola (Fig. 6C). Growth reduction was accompanied by a reduction in the induction of disease symp- toms, which was complemented by the expression of GacA from pIOM100 ( $\mathrm{P}_{n p t I I}:$ :gacA) (Table 2; Fig. 6D). We also tested the mutant strain for induction of the HR in tobacco leaves; however, we found no reproducible differences between the HR induced by IOM50 $(\triangle g a c A)$ and that induced by the wild type, regardless of the inoculation dose used (Fig. 6E).

GacA has been reported to upregulate the expression of $h r p R S$ in P. syringae pv. tomato DC3000 but not in P. syringae pv. syringae B728a (Chatterjee et al. 2003). In DC3000, a mutation in gacA causes a decrease in the expression of $h r p Z, h r c C$, and several effector genes. The DC3000 gacA mutant has a reduced ability to induce HR in tobacco leaves and to induce symptoms and grow within both Arabidopsis and tomato (Chatterjee et al. 2003). A mutation in gacA also affects virulence in $P$. syringae pv. syringae $\mathrm{B} 728 \mathrm{a}$ but not $\mathrm{HR}$ induction in tobacco leaves, and this effect on virulence takes place through its regulation of HrpL-independent virulence determinants (Willis et al. 1990; Chatterjee et al. 2003). Although our results on the expression of $h r p R$ and $h r p L$ in acidic conditions suggest that GacA could upregulate their expression in $P$. syringae pv. phaseolicola, as is the case in $P$. syringae pv. tomato (Fig. 6A), growth attenuation of the $\triangle$ gacA mutant (IOM50) in bean (Fig. 6D), not accompanied by a reduction on HR induction in tobacco (Fig. 6E), is closer to the phenotypes of a $P$. syringae pv. syringae gacA mutant, in which GacA does not regulate the expression of the hrp/hrc genes (Chatterjee et al. 2003). In order to determine whether the attenuation in growth associated with $\triangle g a c A$ mutation in P. syringae pv. phaseolicola is due to a role of GacA in upregulating $h r p / h r c$ gene expression, we generated a $\Delta g a c A$ $\Delta h r p L$ double mutant strain (IOM72) (Table 1) and analyzed its growth in mixed infection with the $\Delta h r p L$ single-mutant strain (IOM7) using COI assays. If the role of GacA in virulence was HrpL independent, the attenuations caused by both mutations would be additive, thus causing the double-mutant strain to be more attenuated than each of the single mutants. The COI determined for the double-mutant strain in mixed infection with IOM7 $(\Delta h r p L)$ was not significantly different from 1.0 (Fig. 6C). An in planta growth assay shows how IOM7 ( $\Delta h r p L)$, although severely attenuated in growth, still displays an increase of close to 100 -fold in bacterial CFU per milliliter by $14 \mathrm{dpi}$ (Fig. 6F). Thus, an additional attenuation caused by the $\Delta$ gacA mutation (between two- and threefold) could still be detected in the double mutant by our growth assays, if they were additive. These results indicate that the presence of a $\triangle g a c A$ mutation in an $h r p L$-defective background does not cause any further growth attenuation and, therefore, the contribution of GacA to virulence is dependent on the function of HrpL.

\section{Analyzing the role of $\mathrm{HrpA}$ in the regulation of $h r p R, h r p S$, and $h r p L$ gene expression.}

In $P$. syringae pv. tomato DC3000, HrpA has been shown to upregulate the expression of the hrpRS operon (Wei et al. 2000). To determine whether HrpA plays a similar role in $P$. syringae pv. phaseolicola, we analyzed expression of the $h r p R S$ operon in the wild-type strain and a $\triangle h r p A$ mutant derivative (strain IOM49) (Table 1). In laboratory conditions, we found no significant differences in the expression of $h r p R$ between wild type and IOM49 by either 120 or 240 mpi (Fig. 7A, inset), although the mutant strain showed a 2.5- to 3.5-fold decrease by 480 to $720 \mathrm{mpi}$ (Fig. 7A). A similar trend was found when expression of $h r p L$ was analyzed (Fig. 7B). Clearer results could be seen using a probe for the hrpS gene, with a 13-fold decrease in expression in the mutant that could be already detectable by $240 \mathrm{mpi}$ depending on the experiment (Fig. 7C, inset).

In planta expression analysis showed a significant decrease in $h r p S$ and $h r p L$ by 120 mpi that was no longer detectable by 
480 mpi (Fig. 8A and B). A similar, although delayed, effect of the $h r p A$ mutation could also be seen on the expression of the $h r c C$ gene (Fig. 8C). However, no significant differences could be established at that time from the analysis of $h r p R$ (Fig. 8D). Most studies agree that $h r p R$ and hrpS are expressed as an operon (Hutcheson et al. 2001; Chatterjee et al. 2003), although it has also been reported that they are expressed separately in P. syringae pv. phaseolicola (Grimm et al. 1995). We analyzed promoter activity upstream of the hrpS ORF using plasmidencoded transcriptional fusions to a promoterless lacZ gene in both Escherichia coli and P. syringae pv. phaseolicola but could not detect any activity (data not shown). In any case, the
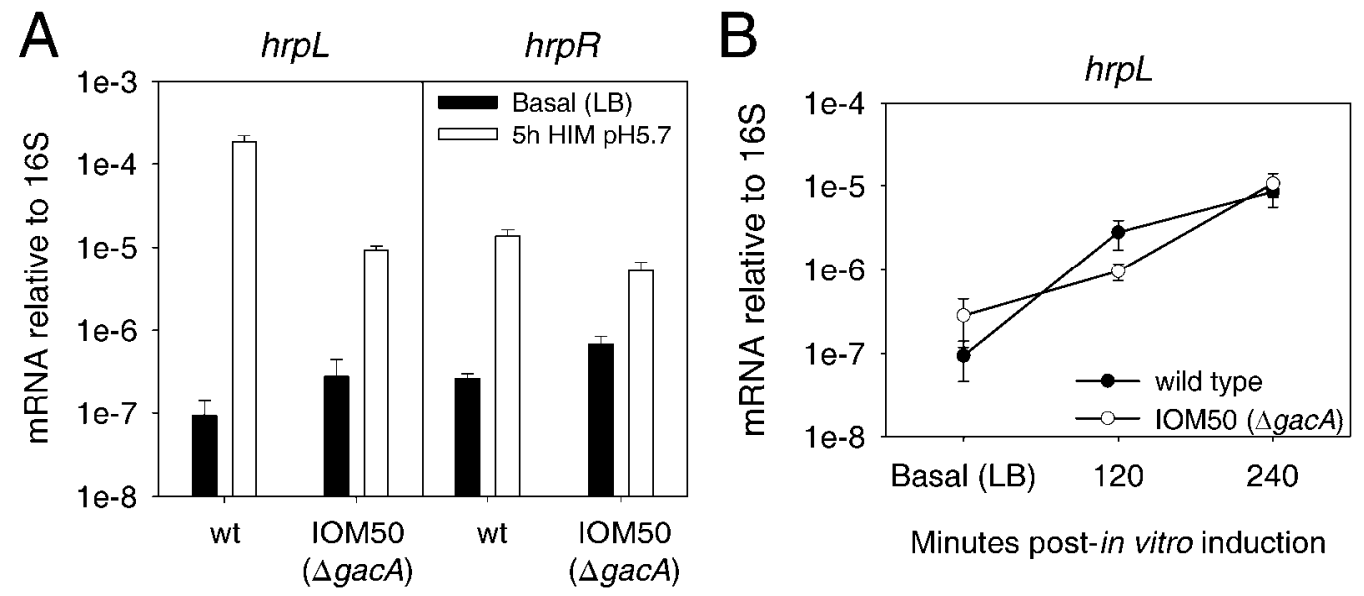

Minutes post-in vitro induction

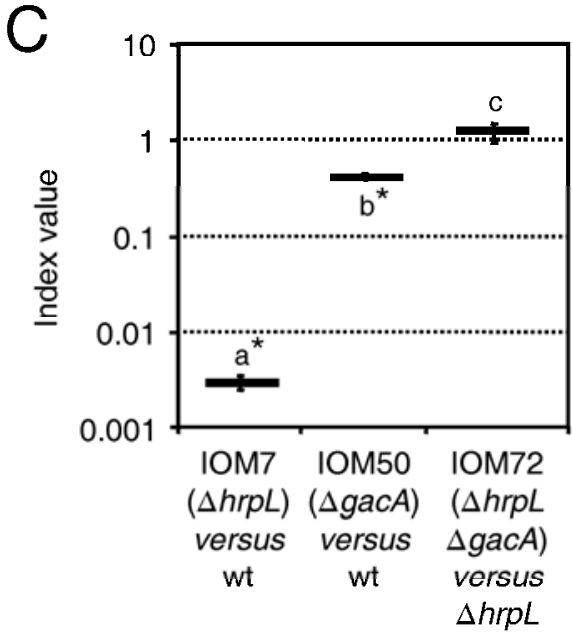

$\mathrm{D}$

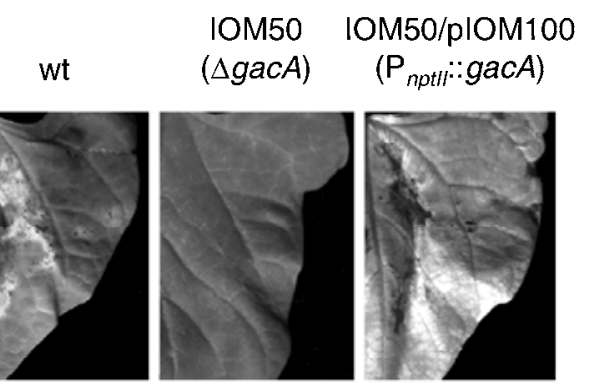

$E$

$10 \mathrm{M} 50$

wt $\quad(\triangle g a c A)$

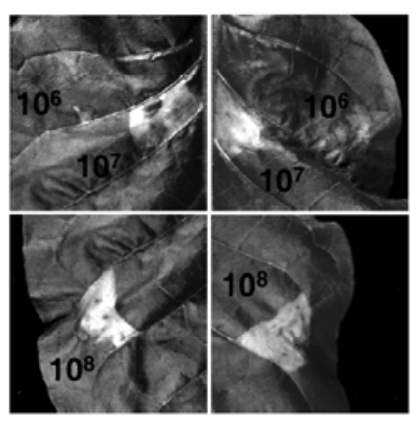

$\mathrm{CFU} / \mathrm{ml}$

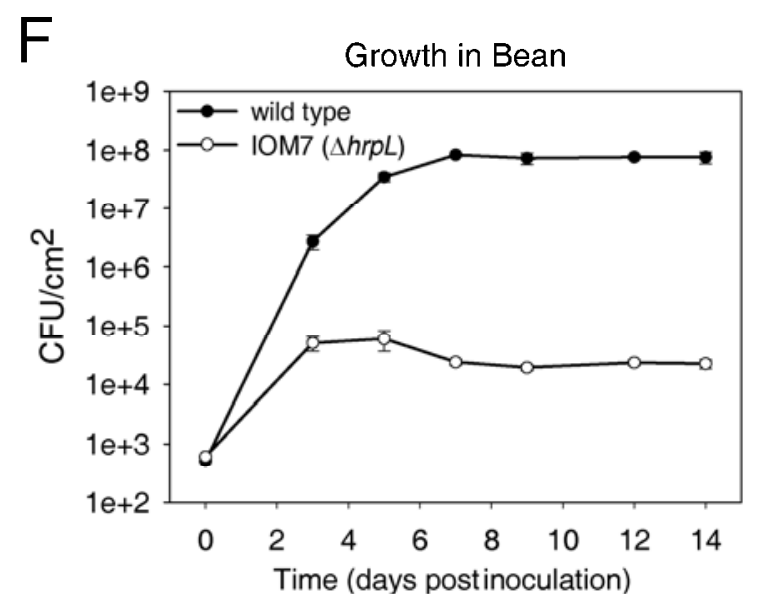

Fig. 6. Analysis of a gacA mutant. A, Transcript levels of the wild type (wt) compared with $\triangle$ gacA mutant in Luria-Bertani (LB) medium (black rectangles) and $5 \mathrm{~h}$ after transfer to transfer to acidic $h r p$-inducing medium from mid-log growth phase of LB cultures (white rectangles) for $h r p L$ (left panel) and $h r p R$ (right panel) genes. B, Induction of $h r p L$ gene in the wt (black circles) and $\triangle g a c A$ mutant (white circles) at 120 and 240 min after transfer to minimal medium (mpi). Basal measures correspond to transcripts levels in LB medium prior to induction. Results shown are obtained from triplicate analyses. Error bars represent the standard deviation. C, Competitive indices (CI) of IOM7 $(\Delta h r p L)$ or IOM50 $(\Delta g a c A)$ growing in a mixed infection with the wt are shown, as well as the cancelled-out index (COI) of IOM72 $(\Delta h r p L \Delta g a c A)$ versus IOM7 $(\Delta h r p L)$. Asterisks indicate indices significantly different from 1 and different letters indicate indices significantly different from each other, as established using Student's $t$ test $(P<0.05)$. Each CI value represents the mean from three independent experiments. D, Disease symptoms induced in bean leaves by infiltration with of the wt, IOM50 ( $\triangle g a c A)$, and IOM50 carrying pIOM100 $\left(\mathrm{P}_{\text {nptII }}:: g a c A\right)$ at $10^{4} \mathrm{CFU} / \mathrm{ml}$ at 14 days postinoculation. E, Hypersensitive response induced in tobacco leaves $24 \mathrm{~h}$ after infiltration with different doses of the wt or IOM50 $(\triangle g a c A)$. F, In planta growth assay of the wt (black circles) and IOM7 ( $\triangle h r p L)$ (white circles). 
differences observed between the results obtained using the probes for $h r p R$ and $h r p S$ could be explained by different efficiencies of the probes, expression from different transcriptional units, or differences in messenger (m)RNA stability.

In summary, our results support a role for HrpA in the regulation of the expression of hrpRS in P. syringae pv. phaseoli-
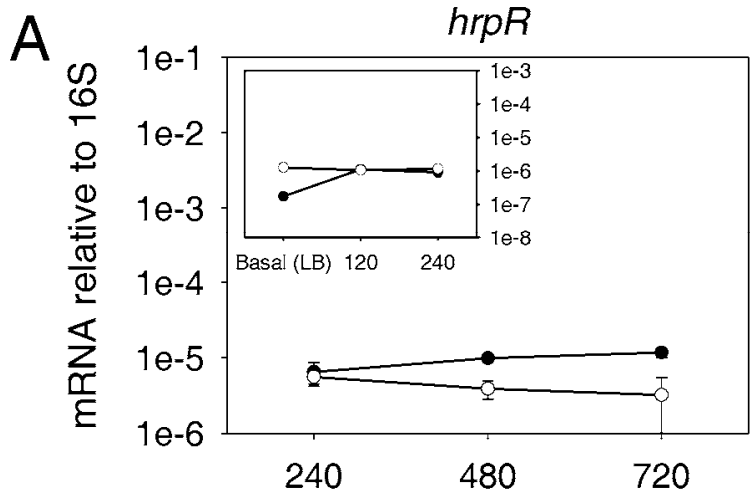

Minutes post-in vitro induction
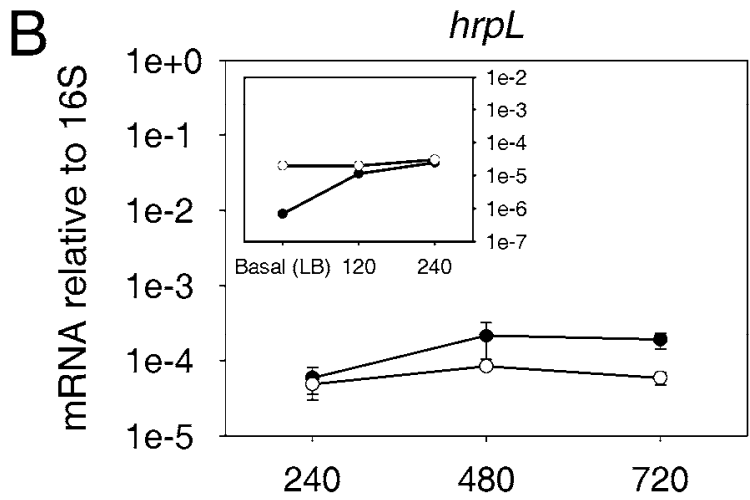

Minutes post-in vitro induction

$\mathrm{C}$

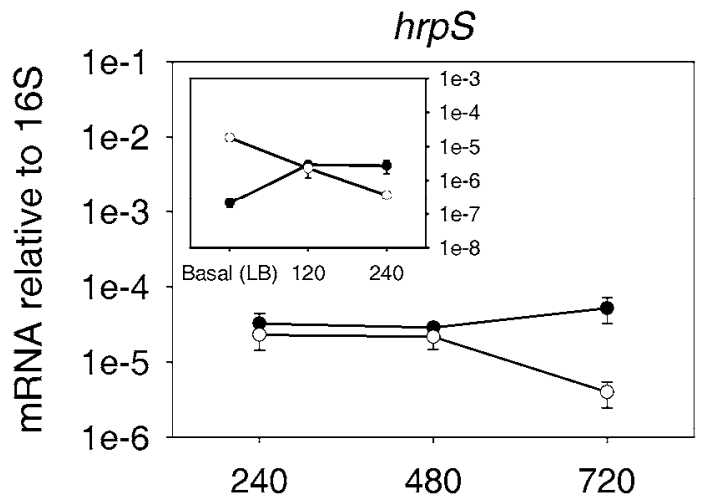

Minutes post-in vitro induction

$\rightarrow$ wild type

$\longrightarrow-10 \mathrm{M} 49(\triangle h r p A)$

Fig. 7. Expression of hypersensitive response and pathogenesis/hypersensitive response conserved ( $h r p / h r c)$ genes in $h r p A$ mutant. Induction of $\mathbf{A}$, $h r p R ; \mathbf{B}, h r p L$; and $\mathbf{C}, h r p S$ genes in wild-type (black circles) and IOM49 $(\triangle h r p A)$ (white circles) strains, at $120,240,480$, or 720 min after transfer to minimal medium. Basal measures correspond to transcripts levels in Luria-Bertani (LB) medium prior to induction. Inserts with earlier time points are included to show the high expression levels in LB prior to induction and the absence in $h r p / h r c$ gene induction for IOM49 ( $\Delta h r p A)$. Results shown are obtained from triplicate analyses. Error bars represent the standard deviation. cola, although not as evident as it has been shown in $P$. syringae pv. tomato DC3000 (Wei et al. 2000). Surprisingly, elevated levels of all regulatory transcripts were found in the mutant strain growing in LB medium, and after washing in $\mathrm{MgCl}_{2}$ prior to infiltration into the plant (Figs. 7A through $\mathrm{C}$, insets, and $8 \mathrm{~A}$ through D).

\section{Role of HrpA in regulating the expression of $h r p Z$.}

In most pathovars, HrpA is expressed as part of an operon that also includes downstream gene hrpZ. Expression from the $h r p A$ promoter produces a highly stable transcript that includes just $h r p A$ and a longer, less stable, transcript including $h r p Z$ and downstream genes (Taira et al. 1999; Hienonen et al. 2002, 2004). However, transcription of $h r p A$ and $h r p Z$ has been reported to take place separately in $P$. syringae pv. phaseolicola (Lee et al. 2001), with stability of the hrpA transcript also being higher than that of hrpZ (Thwaites et al. 2004). When expression of $h r p Z$ was analyzed, we found that the effect of the $\triangle h r p A$ mutation on its expression under inducing conditions was different from that previously detected for the other $h r p / h r c$ genes analyzed. Although, in LB, hrpZ expression showed an elevated expression in the mutant, similar to that of the other $h r p / h r c$ genes, the $\Delta h r p A$ mutation completely abolished induction of $h r p Z$ expression, with transcripts level staying unaltered throughout the duration of the experiments, rendering maximal levels 10- to 100-fold lower than those of the wild type in both inducing medium and in planta (Fig. 9A and B). Considering that i) $h r p A$ and $h r p Z$ are transcribed separately in $P$. syringae pv. phaseolicola, ii) transcription of the antibiotic resistance gene within the nonpolar cassette associated with the $\triangle h r p A$ mutation takes place in the opposite direction from that of the $h r p A$ and $h r p Z$ genes, and iii) $h r p Z$ transcription in $\mathrm{LB}$ is, in fact, higher in the $\triangle h r p A$ mutant than in the wild type, our results indicate that $\operatorname{HrpA}$ has a differential effect on the expression of the hrpZ gene. Interestingly, Wei and colleagues (2000) also found lower RNA levels of $h r p Z$ in the $P$. syringae pv. tomato hrpA mutant, although the implications of this result were not discussed. We have also found a differential regulation of another $h r p / h r c$ operon in the case of the upregulation of the expression of the $h r p C$ operon by HrpG (Ortiz-Martín et al. 2010). The different responses of the $h r p / h r c$ operons could be due to the presence of different operator regions other than the $h r p$ box acting in the promoters, or to differences in the binding affinity of HrpL to each of the hrp boxes.

\section{Ectopic expression of HrpA.}

We analyzed the expression of $h r p L, h r p R$, and $h r p S$ in strains ectopically expressing HrpA from two different promoters $\left(\mathrm{P}_{\text {lac } z}:\right.$ :hrpA in plasmid pIOM26 and $\mathrm{P}_{n p t I I}:$ : $r p A$ in plasmid pIOM33) (Table 2). In keeping with the proposed role for HrpA in the upregulation of $h r p / h r c$ expression, levels of $h r p L$ and $h r p R$ transcripts were elevated in the wild-type strain carrying any of the plasmids throughout the course of the experiment (Fig. 10A and B). No clear differences could be detected using the hrpS probe (data not shown).

All mutants and plasmids used in this study were routinely tested for complementation. When the $\triangle h r p A$ mutant strain carried either of these two plasmids (pIOM26 $\mathrm{P}_{\text {lac }}:$ :hrpA or pIOM33 $\mathrm{P}_{n p t I I}:$ :hrpA), no complementation was found for the induction of HR (Table 3). A similar lack of complementation was obtained when using plasmids expressing different lengths of the $h r p A$ region (including different lengths of untranslated region sequences) or simultaneously expressing HrpA and HrpZ, or HrpR, HrpS, and HrpA, from either promoter. All these plasmids had been sequenced to rule out mutations and, therefore, should express functional HrpA at the corresponding 
levels. Full complementation of HR induction was only achieved when the mutant strain carried plasmid pPPY430 that contains most of the $h r p / h r c$ locus from P. syringae pv. phaseolicola (Mansfield et al. 1994). These results could be explained by i) cis-expression of $h r p A$ being required for its function, ii) problems associated to elevated levels of HrpA, or iii) a secondary mutation located in the $h r p / h r c$ locus being responsible for some of the in planta phenotypes of the $\triangle h r p A$ strain.

In support of the second explanation, ectopic expression from most of these plasmids (Table 3), except for plasmids pPPY430 (containing most of the $h r p / h r c$ locus), pIOM50 ( $\left.\mathrm{P}_{\text {lac } z}: h r p R S A\right)$, and pIOM51 $\left(\mathrm{P}_{n p t I I}: \because h r p R S A\right)$ from either the wild-type $P$. syringae pv. phaseolicola 1448 a strain or the $P$. syringae pv. tomato wild-type representative DC3000 strain, somehow interfere with T3SS function, abolishing induction of the HR in tobacco, bacterial growth, and symptom development (Table 3). However, ectopic expression of the HrpA protein from DC3000 (1448a carrying pDN18-N-hrpA $A_{P t o}$ ) did not cause such an effect (Table 3). Therefore, the negative effect that HrpA ectopic overexpression has on the ability of a wild-type strain to elicit host responses seems to be specific to the HrpA $A_{P p h 1448 a}$ protein. It is worth noting that the sequence of HrpA varies considerably between pathovars and a recent report has shown that diversifying selection drives evolution of HrpA, thus maintaining its genetic diversity (Guttman et al. 2006). Although we could not entirely rule out other explanations, it seems that ectopic expression of $\mathrm{HrpA}_{\mathrm{Pph} 1448 \mathrm{a}}$ interferes with either expression or proper assembly of the T3SS, which would explain the difficulties for complementing the mutant strain. Considering that concomitant ectopic expression of HrpA, HrpR, and HrpS does not affect the ability of the wild type to induce the HR in tobacco, interference seems more likely to take place at the expression level. However, further work would be necessary to elucidate this question.

\section{HrpA and $h r p / h r c$ expression in rich medium.}

We have found that a mutation in $h r p A$ causes an unexpected increase in the expression in LB of most $h r p$ genes analyzed ( $h r p L, h r p R, h r p S$, and $h r p Z$ ) (Figs. 8, 9, and 10). We have also found that mutation of the $h r c C$ gene upregulates bacterial motility in inducing medium (Fig. 5B). In the accompanying report, we describe how HrpG acts as positive regulator of the $h r p C$ operon and yet, when deleted, also causes an unexpected increase in the expression of this operon in rich medium (Ortiz-Martín et al. 2010). The level of expression of $h r p Z$ and $h r c C$ in the $\triangle h r p A$ and $\triangle h r p G$ mutant strains, respectively, was very similar in $L B$ to their levels after induction in minimal medium, regardless of the time postinoculation (Fig. 9A and B) (Ortiz-Martín et al. 2010). Although starting from an elevated level in LB, the curves of induction of the expression of these genes were almost flat in both mutant strains, thus rendering final levels lower than wild type and indicating that full expression is not achieved in either the $h r p A$ or the $h r p G$ mutant strains due to a failure in inducing $h r p / h r c$ gene expression. We have also found that HrpV repression of the $h r p / h r c$ gene expression involves HrpT and also occurs in LB medium (OrtizMartín et al. 2010). These results suggest that basal expression of $h r p / h r c$ genes may be important to keep the system primed for rapid induction when required for infection. In such a model, the presence of a budding apparatus would be necessary to achieve full induction of the $h r p / h r c$ genes; hence, structural mutations such as those affecting $h r p A$ or $h r p G$ (necessary for induction of the $h r p C$ operon) could hinder full induction. Furthermore, HrpV and HrpT would have the biological role of
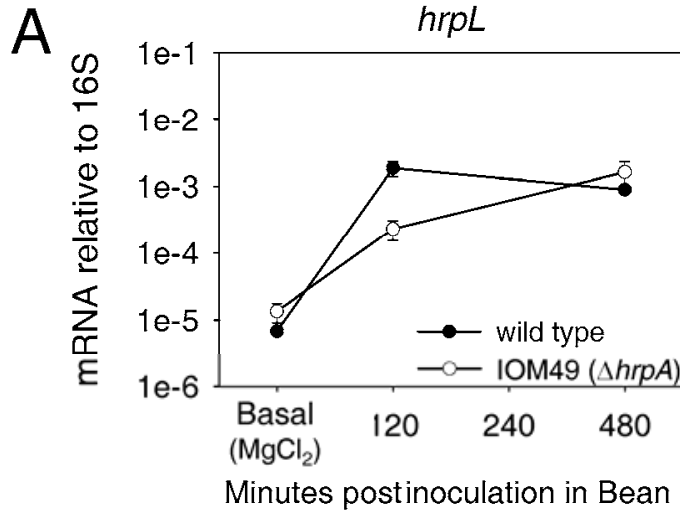

C

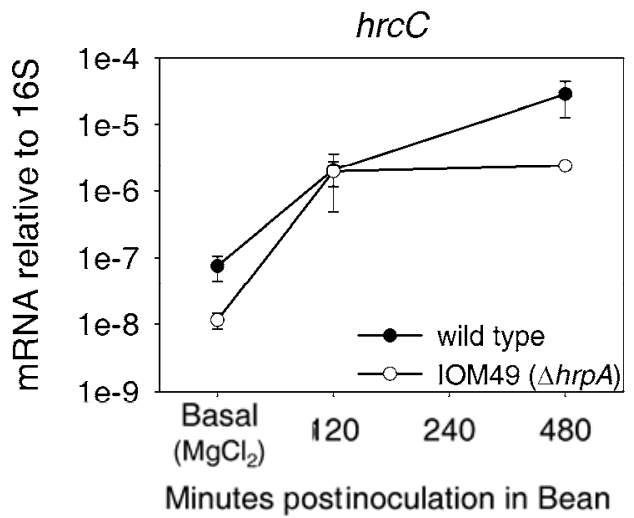

B

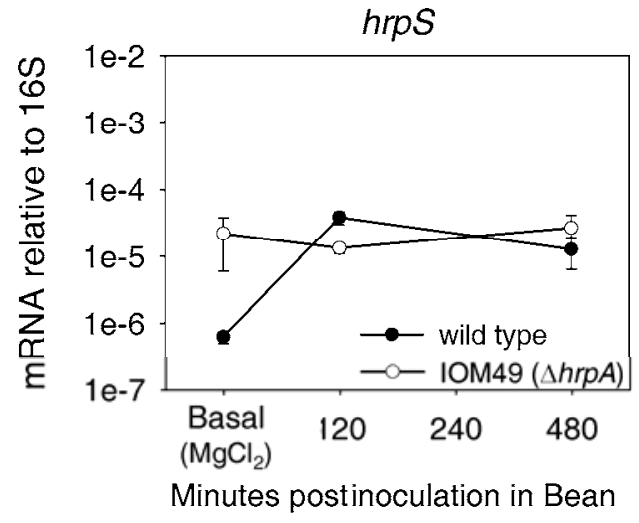

$\mathrm{D}$

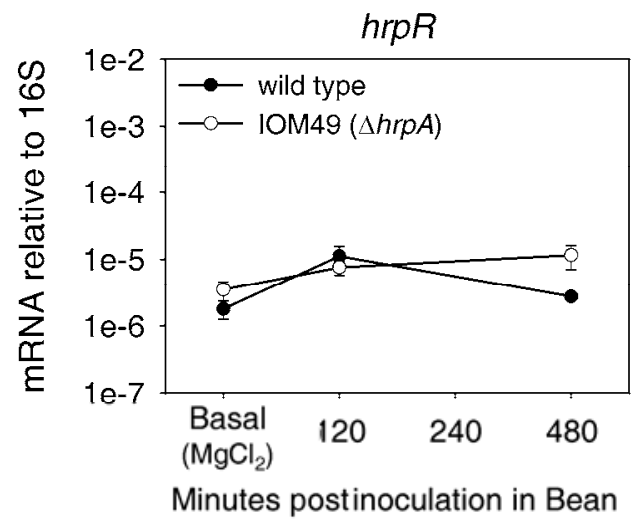

Fig. 8. In planta expression of hypersensitive response and pathogenesis/hypersensitive response conserved ( $h r p / h r c)$ genes in planta in wild-type and $\Delta h r p A$ mutant strains. Induction of $\mathbf{A}, h r p L ; \mathbf{B}, h r p S ; \mathbf{C}, h r c C$; and $\mathbf{D}, h r p R$ genes in the wild type (black circles) and $\Delta h r p A$ mutant (white circles) at 120 and 480 min postinoculation into leaves of the susceptible bean cv. Canadian Wonder. Basal measures correspond to transcripts levels after washing in $10 \mathrm{mM} \mathrm{MgCl}_{2}$ prior to inoculation. Results shown are obtained from triplicate analyses. Error bars represent the standard deviation. 
preventing premature activation of the system into full function until the appropriate signals for induction have been encountered. To analyze these questions further, we carried out expression analysis in a $\Delta h r c C$ mutant (IOM3). As expected, this mutation abolished the induction of both HR in tobacco leaves as well as bacterial growth and symptom induction in bean plants, defects that were complemented when HrcC was expressed from a $\mathrm{P}_{\text {lac }}$ promoter (pIOM21) (Fig. 11A, upper and lower panels, respectively, and data not shown). As expected, $\mathrm{HrcC}$ did not affect the final levels of expression reached after induction (Fig. 11B), in keeping with not having a regulatory role. However, in LB, the $\Delta h r c C$ mutant strain displayed a clear increase on the expression of genes $h r p L, h r p R$, and $h r p F$ (although not in hrpA) (Fig. 11C). Thus, these results support the notion of a budding apparatus primed yet not fully functioning existing under repressing conditions, ready for rapid response upon activation, being a requirement for full activation of the $h r p / h r c$ gene expression. However, the means by which this regulation could be achieved must be necessarily complex, with differential regulation of structural operons taking place and many regulatory and structural proteins involved.

\section{Concluding remarks.}

Our results show that HrpL acts as a general regulator of virulence functions, because it upregulates non-T3SS virulence determinant and downregulates flagellar function. Because flag-
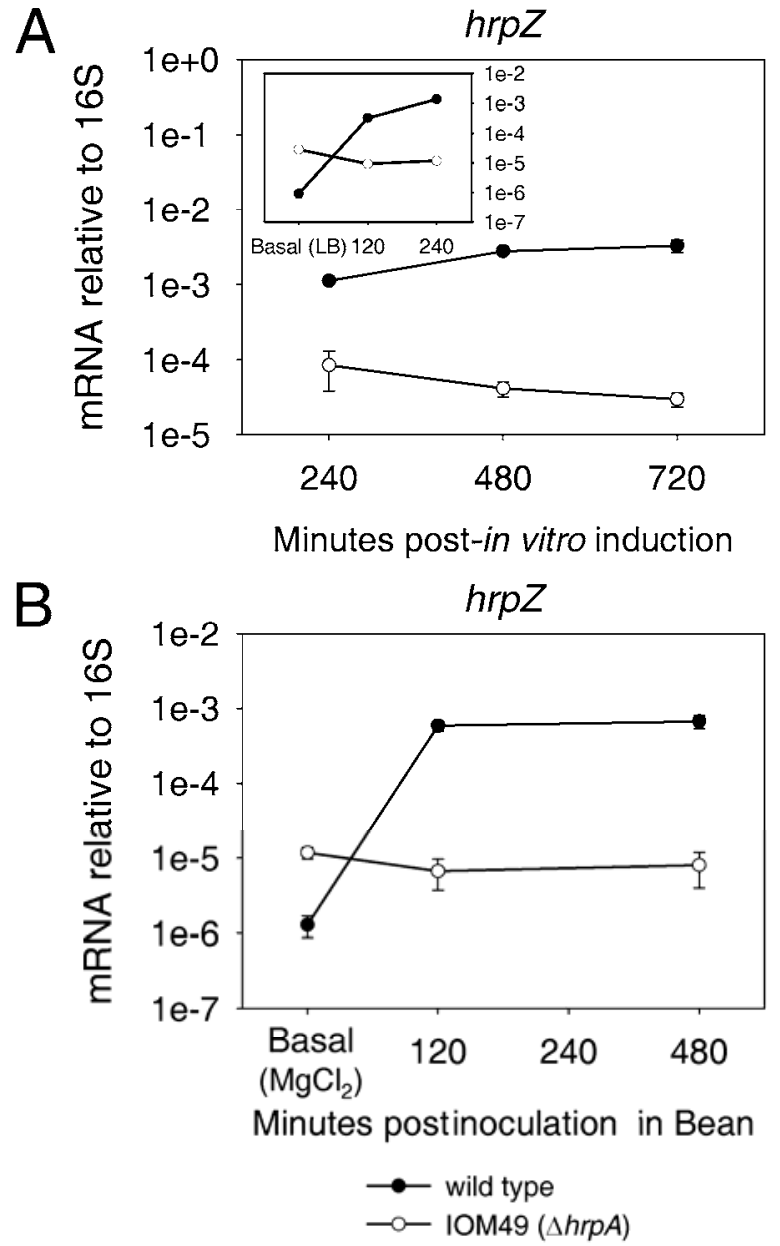

Fig. 9. Analysis of $h r p Z$ gene expression in the wild type (black circles) and $\triangle h r p A$ mutant (white circles) in either $\mathbf{A}$, in vitro or $\mathbf{B}$, in planta conditions. Basal transcript levels correspond to $\mathbf{A}$, levels in Luria-Bertani medium or $\mathbf{B}, 10 \mathrm{mM} \mathrm{MgCl}_{2}$ prior to induction. Results shown are obtained from triplicate analyses. Error bars represent the standard deviation. ellin is a known pathogen-associated molecular pattern that triggers host defense responses (Zipfel et al. 2004), downregulation of the expression of flagella upon contact with the plant apoplast, in coordination with the activation of the T3SS expression and that of other virulence functions, would be advantageous for the pathogen. Coordinated regulation of these functions is probably coupled with that of other aspects of bacterial general physiology through the action of GacA, because its contribution to virulence is entirely dependent on the function of HrpL. Our results also show that mutation of the hrpRS genes promotes growth of a strain carrying a $\Delta h r p L$ deletion. This result can be explained by the hrpRS mutation lifting previously reported HrpR/S repression of housekeeping genes (Lan et al. 2006). HrpR/S downregulation of housekeeping genes could be advantageous by directing bacterial resources toward virulence functions. However, in the absence of a functional HrpL and its upregulated virulence determinants, downregulation of housekeeping functions could determine a more severe growth defect, probably through a lack of fitness.

Our results also show that mutations that affect structural components of the secretion apparatus (HrpA, HrcC, and HrpG that are necessary for expression of the $h r p C$ operon) (OrtizMartin et al. 2010) disrupt repression in rich medium. Furthermore, at least two of these mutations ( $\triangle h r p A$ and $\Delta h r p G$ ) hinder induction of the $h r p / h r c$ gene. On the basis of these results, we propose a model in which basal level of $h r p / h r c$ gene expression under repressing conditions would be necessary for full activation of the system. This basal expression would guarantee a low level of protein production, maybe even produce a budding yet functional apparatus, thus accelerating the T3SS activation process. Our results also indicate that this basal level of expression is HrpL-independent. Considering that the events defining the fate of the bacteria-plant interaction take place very quickly upon bacterial entry into the plant apoplast, such a mechanism, with a potential impact on the timing of effector translocation, among other events, would represent a clear evolutionary advantage for the pathogen. In this regard, although effector translocation is believed to take place within minutes once the secretion apparatus has been assembled, full assembly of the apparatus is estimated to take close to $30 \mathrm{~min}$ to be completed (G. Cornelis, personal communication).

Our model also proposes that regulation of the $h r p / h r c$ gene expression during growth within the plant could be coupled to the assembly and function of the T3SS. This would take place at several levels, one of which would be carried out by HrpA upregulating expression of the $h r p / h r c$ genes through a positive feedback mechanism that is essential for the expression of the $h r p Z$ operon. Other levels of this regulation are presented and discussed by Ortiz-Martin and associates (2010). This regulation would likely take place through $\mathrm{HrpL}$, because a mutation disrupting the proper assembly and function of the secretion apparatus $(\Delta h r c C)$ increases flagellar function that is downregulated through the action of HrpL.

\section{MATERIALS AND METHODS}

Bacterial strains, plasmids, and growth conditions.

Bacterial strains and plasmids used in this work are listed in Table 1. E. coli and P. syringae pv. phaseolicola strains were grown at 37 and $28^{\circ} \mathrm{C}$, respectively, with aeration in LB medium. Additional strains and plasmids are described in the accompanying report (Ortiz-Martín et al. 2010). For induction of hrp/hrc genes, bacteria were grown overnight in $\mathrm{LB}$ at $25^{\circ} \mathrm{C}$, supplemented with the appropriate antibiotic. Cells were washed twice in $10 \mathrm{mM} \mathrm{MgCl}$ and grown in $h r p$-inductive minimal medium (HIM), containing $10 \mathrm{mM}$ fructose (Huynh et al. 1989) and $\mathrm{pH} 7.0$ at $25^{\circ} \mathrm{C}$, previously adjusted to an opti- 
cal density at $600 \mathrm{~nm}$ of 0.5 . Antibiotics were used at the following concentration: ampicillin $(100 \mu \mathrm{g} / \mathrm{ml}$ for E. coli strains; $100 \mu \mathrm{g} / \mathrm{ml}$ for liquid cultures and $300 \mu \mathrm{g} / \mathrm{ml}$ for plates for $P$. syringae pv. phaseolicola strains), kanamycin (50 $\mu \mathrm{g} / \mathrm{ml}$ for $E$. coli strains and $15 \mu \mathrm{g} / \mathrm{ml}$ for $P$. syringae pv. phaseolicola strains), chloramphenicol $(30 \mu \mathrm{g} / \mathrm{ml}$ for $E$. coli strains and 6 $\mu \mathrm{g} / \mathrm{ml}$ for $P$. syringae pv. phaseolicola strains), tetracycline $(10 \mu \mathrm{g} / \mathrm{ml})$, and streptomycin $(50 \mu \mathrm{g} / \mathrm{ml})$.
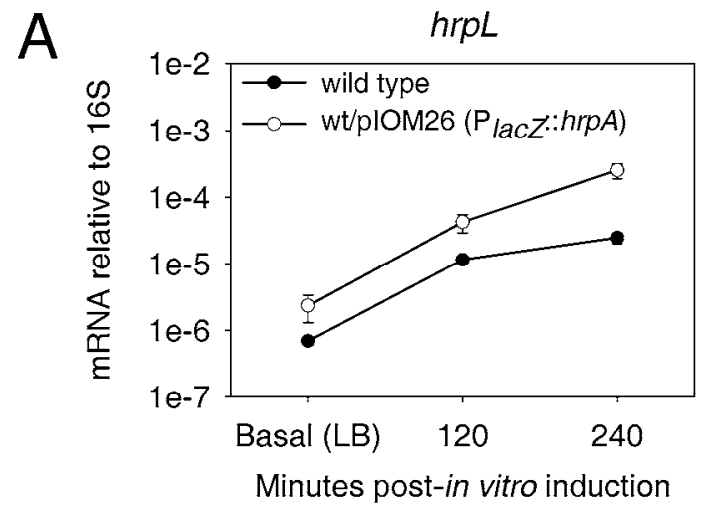

B

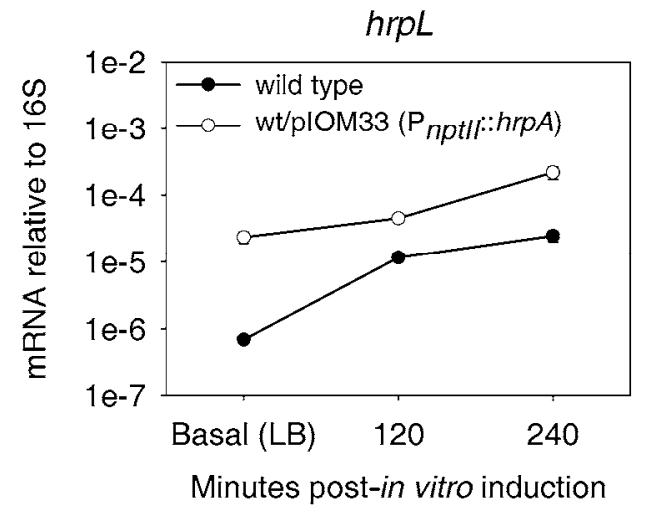

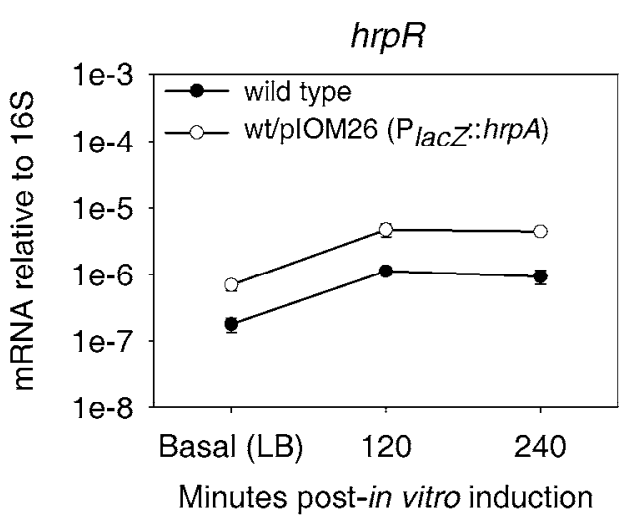

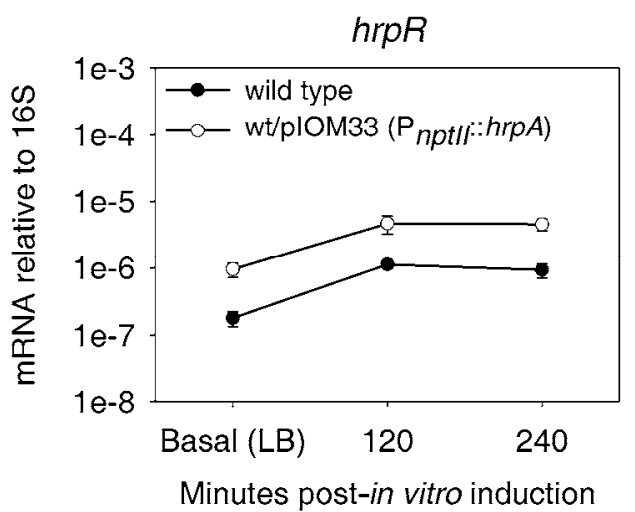

Fig. 10. Ectopic expression of HrpA. Expression of $h r p L$ and $h r p R$ genes in the wild type (black circles) and the wild type expressing HrpA under the control of either A, lacZ or B, nptII promoters (white circles) at 120 and 240 min after transfer to minimal medium. Basal measures correspond to transcripts levels in Luria-Bertani medium prior to induction. Results shown are obtained from triplicate analyses. Error bars represent the standard deviation.

Table 3. Induction of hypersensitive response (HR) in tobacco, symptoms in bean, and competitive indices (CI) of different Pseudomonas syringae strains

\begin{tabular}{|c|c|c|c|}
\hline Strains & $\mathbf{H R}^{\mathbf{a}}$ & $\mathbf{S B}^{\mathbf{b}}$ & $\mathbf{C I} \pm \mathrm{SE}^{\mathrm{c}}$ \\
\hline \multicolumn{4}{|l|}{ P. syringae pv. phaseolicola $1448 \mathrm{a}$} \\
\hline Wild type (wt) & + & III & \\
\hline IOM49 $(\Delta h r p A)$ & - & I & $0.0038 \pm 0.0004$ \\
\hline $\operatorname{IOM} 49(\Delta h r p A) / \mathrm{pIOM} 26\left(\mathrm{P}_{\text {lacz }}:\right.$ : hrpA) & - & n.d. & n.d. \\
\hline IOM49 $(\Delta h r p A) /$ pIOM33 $\left(\mathrm{P}_{n p t I I}:\right.$ hrpA) & - & n.d. & n.d. \\
\hline IOM49 ( $\Delta h r p A) /$ pIOM28 ( $\left.\mathrm{P}_{\text {lac }}:: h r p A Z\right)$ & - & n.d. & n.d. \\
\hline IOM49 $(\Delta h r p A) /$ pIOM50 $\left(\mathrm{P}_{l a c z}:: h r p R S A\right)$ & - & n.d. & n.d. \\
\hline IOM49 $(\Delta h r p A) /$ pIOM51 $\left(\mathrm{P}_{n p t I I}:: h r p R S A\right)$ & - & n.d. & n.d. \\
\hline IOM49 $(\Delta h r p A) / \mathrm{pPPY} 430$ & + & n.d. & n.d. \\
\hline IOM49 $(\Delta h r p A) / \mathrm{pDN} 18-\mathrm{N}-h r p A_{P t o}$ & - & n.d. & n.d. \\
\hline IOM49 $(\Delta h r p A) / \mathrm{pDN} 18-\mathrm{N}-h r p A_{P p h}$ & - & n.d. & n.d. \\
\hline $\mathrm{wt} / \mathrm{pIOM} 26\left(\mathrm{P}_{\text {lacz }}:\right.$ hrpA $)$ & - & II & $0.0025 \pm 0.0011$ \\
\hline $\mathrm{wt} / \mathrm{pIOM} 33\left(\mathrm{P}_{n p t I}:\right.$ $\left.: h r p A\right)$ & - & II & $0.0014 \pm 0.0003$ \\
\hline $\mathrm{wt} / \mathrm{pPPY} 430$ & + & n.d. & n.d. \\
\hline $\mathrm{wt} / \mathrm{pIOM} 28\left(\mathrm{P}_{\text {lac }}:: h r p A Z\right)$ & - & n.d. & n.d. \\
\hline wt/pIOM50 ( $\mathrm{P}_{\text {lac }}:$ : $\left.r p R S A\right)$ & + & n.d. & n.d. \\
\hline wt/pIOM51 $\left(\mathrm{P}_{n p t I I}:: h r p R S A\right)$ & + & n.d. & n.d. \\
\hline $\mathrm{wt} / \mathrm{pDN} 18-\mathrm{N}-h r p A_{P t o}$ & + & n.d. & n.d. \\
\hline \multicolumn{4}{|l|}{ P. syringae pv. tomato DC 3000} \\
\hline Wild type (wt) & + & n.d. & n.d. \\
\hline$\triangle h r p A$ & - & n.d. & n.d. \\
\hline$\Delta h r p A / \mathrm{pDN} 18-\mathrm{N}-h r p A_{P t o}$ & + & n.d. & n.d. \\
\hline$\Delta h r p A / \mathrm{pIOM} 26\left(\mathrm{P}_{\text {lacz }}:\right.$ :hrpA) & - & n.d. & n.d. \\
\hline $\mathrm{wt} / \mathrm{pDN} 18-\mathrm{N}-h r p A_{P t o}$ & + & n.d. & n.d. \\
\hline $\mathrm{wt} / \mathrm{pIOM} 26\left(\mathrm{P}_{\text {lacz }}:\right.$ hrpA $)$ & - & n.d. & n.d. \\
\hline
\end{tabular}

${ }^{a}$ Elicitation of $\mathrm{HR}(+)$ or no HR (-) in tobacco leaves inoculated with $10^{8} \mathrm{CFU} / \mathrm{ml}$ bacterial suspensions.

${ }^{\mathrm{b}}$ Symptoms in bean. I: without symptoms; II: some chlorotic spots on the infiltrated zone; III: wild-type symptoms, chlorotic halo and water soak spots; n.d. = not determined.

${ }^{\mathrm{c}} \mathrm{CI}$ of the wild-type strain versus the derivatives $P$. syringae $\mathrm{pv}$. phaseolicola strains; $\mathrm{SE}=$ standard error and $\mathrm{n} . \mathrm{d} .=$ not determined. 
Plasmids generated in this work are listed in Table 2. DNA fragments for cloning were PCR amplified from genomic DNA of Pseudomonas syringae pv. phaseolicola 1448a using Pfu polymerase (Promega Corp., Madison, WI, U.S.A.). Bluntended DNA fragments encoding the target ORF were cloned into the EcoRV site of either pBBR1MCS-4 (pIOM26, pIOM50) or pAMEX (pIOM33, pIOM51, pIOM100) to create low- and high-expression plasmids. To obtain pIOM21 and pIOM22, the ORF from $h r c C$ and $h r p L$ were amplified using primers that introduced a $K p n I$ restriction site at the $5^{\prime}$ and a SacII site at the $3^{\prime}$ ends of the amplified fragment. PCR products were digested with KpnI and SacII, and cloned into the KpnI-SacII sites of pBBR1MCS-4. To generate pIOM28, a DNA fragment that contains $h r p A-h r p Z$ was amplified using primers that introduced a $K p n I$ restriction site at the $5^{\prime}$ and a $X b a \mathrm{I}$ site at the $3^{\prime}$ ends of the amplified fragment. PCR product was digested with $K p n I$ and $X b a \mathrm{I}$ and cloned into the KpnI$X b a \mathrm{I}$ sites of pBBR1MCS-4. To obtain pDN18-N-hrpA $A_{P p h}$, pDN18-N-hrpA $A_{\text {Pto }}$ (Taira et al. 1999) was digested with EcoRI and BamHI, releasing the hrpA gene from P. syringae pv. tomato. Klenow fragment (Favorgen Biotech Corporation, Kaohsiung, Taiwan) was used to generate blunt ends in the digested plasmid, into which a blunt-ended DNA fragment containing hrpA amplified from $P$. syringae pv. phaseolicola was cloned. Primers used for their generation are included as supplementary data (Supplementary Table S1). The fragments introduced in all the plasmids were completely sequenced to guarantee the absence of any PCR-introduced mutation.

\section{DNA manipulation.}

Recombinant DNA techniques were performed following standard methods (Sambrook et al. 2001). Genomic DNA was extracted using the Jet Flex extraction kit (Genomed; Löhne, Germany), and plasmid DNA was extracted using a Favor-prep Plasmid DNA miniextraction kit (Favorgen Biotech Corporation). Routine clone analysis was carried out by quick boiling extraction (Holmes and Quigley 1981). DNA gel purification was performed using the Favor-prep Gel/PCR purification mini
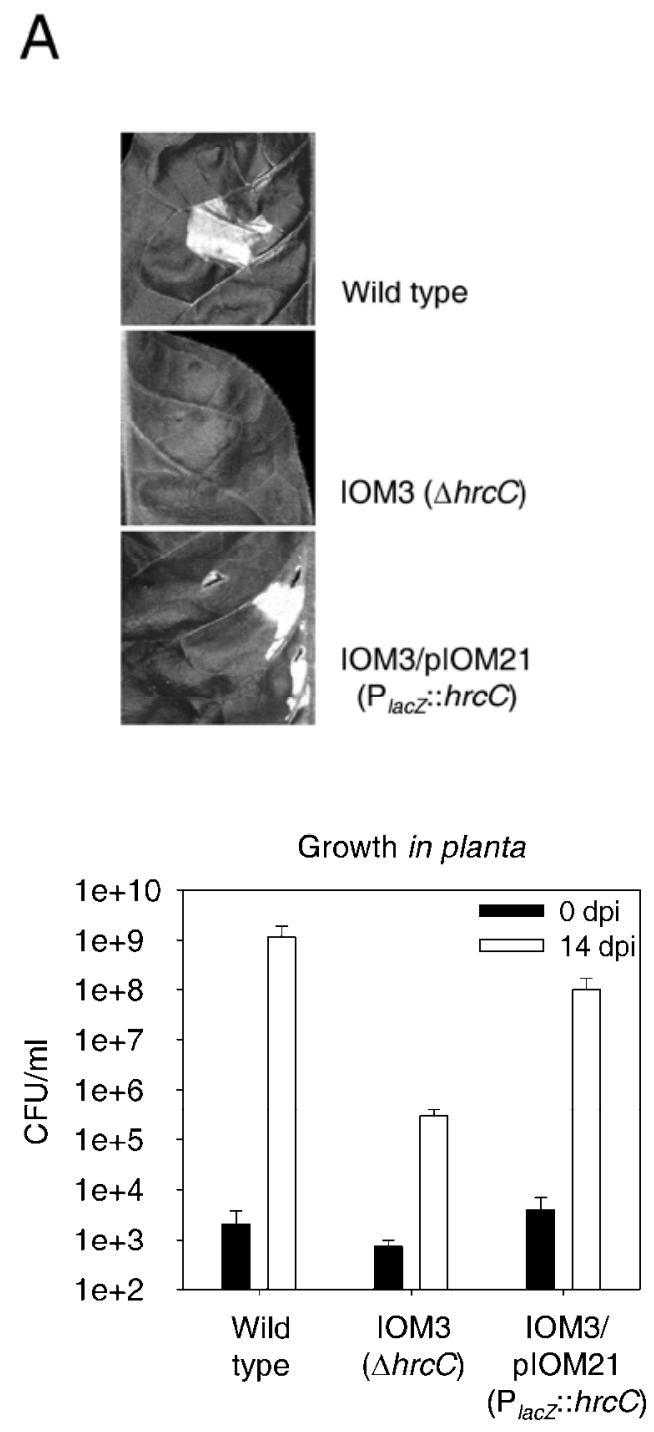

B
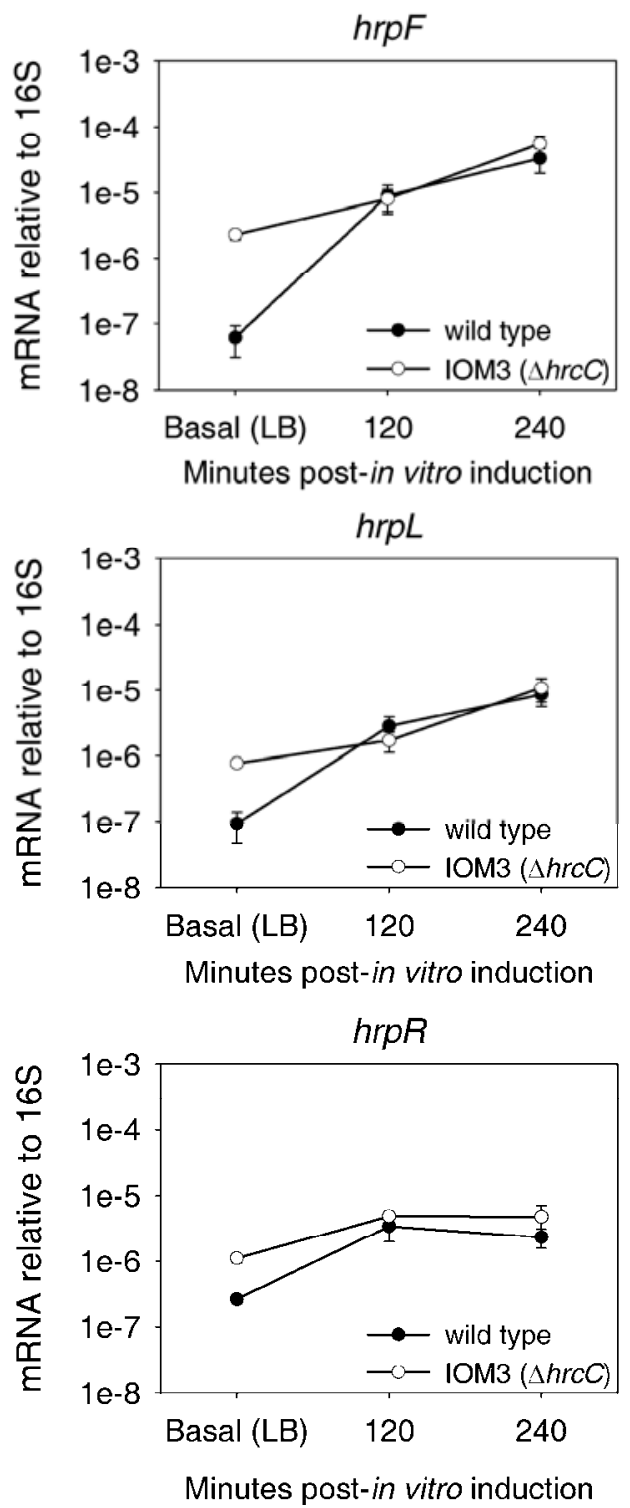

Fig. 11. Analysis of an $h r c C$ mutant. A, Hypersensitive response elicited by $24 \mathrm{~h}$ postinoculation with the wild type, IOM3 ( $\triangle h r c C$ ), and IOM3 carrying pIOM21 ( $\mathrm{P}_{\text {lac }}:$ : $\left.h r c C\right)$, upper panel, and bacterial CFU of the wild type, IOM3 $(\Delta h r c C)$, and IOM3 carrying pIOM21 $\left(\mathrm{P}_{\text {lacz }}: h r c C\right)$, immediately after inoculation into bean leaves ( 0 days postinoculation [dpi]) (black rectangles) or by 14 dpi (white rectangles), lower panel. B, Expression of $h r p F, h r p L$, and $h r p R$ genes in wild-type strain (black circles) and $\Delta h r c C$ mutant (white circles) at 120 and 240 min after transfer to minimal medium. Basal measures correspond to transcripts levels in Luria-Bertani medium prior to induction. Results shown are obtained from triplicate analyses. Error bars represent the standard deviation. 
kit (Favorgen Biotech Corporation). Taq and Pfu Polymerases or Expand high-fidelity polymerase (Roche, Mannheim, Germany) was used as appropriate. Plasmids were introduced into bacteria by heat-shock transformation for E. coli strains (Hanahan 1983) and by electroporation (Choi et al. 2005) or triparental mating for Pseudomonas strains (Ditta et al. 1980).

\section{Generation of single and double knockout mutants.}

Plasmids pIOM67, pIOM68, and pIOM82 were generated to obtain $\triangle h r p A, \triangle g a c A$, and $\triangle h r p R S$ mutant strains, respectively (Table 2). A fragment containing approximately $500 \mathrm{bp}$ of each of the $5^{\prime}$ and $3^{\prime}$ regions flanking the target gene ( $h r p A, g a c A$, and $h r p R S)\left(1,000 \mathrm{bp}\right.$ of the $5^{\prime}$ region of $\left.h r p R\right)$ was A/T cloned into pGEM-T (Promega Corp.). This fragment was generated in a three-step procedure developed by Zumaquero and colleagues (A. Zumaquero, A. P. Macho, and C. R. Beuzón, unpublished data) and briefly described in the accompanying report (Ortiz-Martín et al. 2010).

Mutant alleles were marked with the nptII gene, which confers resistance to kanamycin, obtained from pGEM-T-KmFRT$E c o$ RI by plasmid digestion with EcoRI. The resulting fragments were cloned into the EcoRI sites of the pGEMT derivative vectors carrying the mutant alleles generated previously. All plasmids were completely sequenced to guarantee the absence of any PCR-introduced mutation.

pGEMT derivative plasmids (Table 2) were transformed by electroporation into the $P$. syringae pv. phaseolicola $1448 \mathrm{a}$ strain. Transformants were the result of allelic exchange (double-recombination event) and were screened for as described in the accompanying report (Ortiz-Martín et al. 2010). Southern blot analysis was used to confirm that allelic exchange occurred at the correct position in the genome, with a single insertion of the construct. The double-mutant strains (IOM37 and IOM72) were generated following the methodology described by OrtizMartín and associates (2006, 2010, respectively).

\section{CI in planta and in vitro.}

CI assays were performed in bean plants (Phaseolus vulgaris cv. Canadian wonder) to measure growth attenuation as described by Macho and colleagues (2007). Eight-day-old bean plants, grown at 22 to $28^{\circ} \mathrm{C}$ with a photoperiod cycle of 16 and $8 \mathrm{~h}$, light and darkness, respectively, were inoculated with $200 \mu \mathrm{l}$ of a $5 \times 10^{4} \mathrm{CFU} / \mathrm{ml}$ mixed bacterial suspension, containing equal CFU of wild-type and mutant or gene-expressing strains, using a 2-ml syringe without needle. Serial dilutions of the inoculum were plated onto LB agar and LB agar with the appropriate antibiotic to confirm dose and relative proportion between the strains, which should be close to 1. At $14 \mathrm{dpi}$, bacteria were recovered from the infected leaves. Bacterial recovery was carried out by taking five $10-\mathrm{mm}$ diameter discs with a cork borer that were homogenized by mechanical disruption into $1 \mathrm{ml}$ of $10 \mathrm{mM} \mathrm{MgCl}$. Bacterial enumeration was performed by serial dilution and plating of the samples onto agar plates with cycloheximide at $2 \mu \mathrm{g} / \mathrm{ml}$ and the appropriate antibiotic to differentiate the strains within the mixed infection. COI assays were carried out as described for CI assays, using a single- and double-mutant strain within each mixed infection. This index is defined as the ratio between double- and single-mutant CFU in the output sample (Beuzón and Holden. 2001; Beuzón et al. 2001). Competitive indices shown are the mean of three replicates that show typical results obtained from three independent experiments. Errors bars represent standard error. Each CI was analyzed using a homoscedastic and 2-tailed Student's $t$ test and the null hypothesis: mean index is not significantly different from 1 or from other CI value when otherwise specified (with $P$ value $<0.05$ used).

\section{Motility test.}

In all, $20 \mu \mathrm{l}$ of $10^{9} \mathrm{CFU} / \mathrm{ml}$ suspensions in distilled water from overnight culture on LB were deposited at the center of soft agar (2.5 g/liter) HIM plates. The diameter of the bacterial growth halo was assessed after 6 and 8 days of incubation at $25^{\circ} \mathrm{C}$.

\section{RNA extraction and cDNA synthesis.}

RNA was isolated from cells lysates and inoculated leaves using RNAeasy bacteria mini kit (Qiagen. Hilden, Germany), following the instructions provided by the manufacturer. For extractions from bean plants, two discs of $9 \mathrm{~mm}$ were cut from inoculation sites and frozen immediately in liquid nitrogen. After macerating in $500 \mu \mathrm{l}$ of $1 \times$ RNA-protect reagent (Qiagen), samples were incubated at room temperature and centrifuged at $5,000 \times g$ for $10 \mathrm{~min}$. Pellets were resuspended in $100 \mu \mathrm{l}$ of Tris-EDTA containing $100 \mu \mathrm{g}$ of lysozyme (Sigma-Aldrich, St. Louis) and incubated at room temperature for $10 \mathrm{~min}$. DNAse treatment was carried out twice, during and after the extraction process. cDNA were synthesized using Omniscript reverse transcriptase system (Qiagen) with random hexanucleotides (Promega Corp.). After synthesis, cDNAs were diluted 1:20 in molecular-grade biology water (Eppendorf, Hamburg, Germany) and were used as template in the TaqMan real-time PCR. An aliquot of RNA was tested to ensure that no trace of contaminating genomic DNA was detectable.

\section{TaqMan real-time PCR.}

We followed the methodology developed by Thwaites and colleagues (2004). They measured mRNA abundance relative to $16 \mathrm{~S}$. To rule out the effects of any potential variation in the $16 \mathrm{~S}$ expression on our analysis, we initially measured mRNA abundance versus both $16 \mathrm{~S}$ and $g y r B$ and abundance of $g y r B$ mRNA relative to $16 \mathrm{~S}$. Results showed no significant differences between both analyses, except that measurement relative to $16 \mathrm{~S}$ were shown to be more reproducible (data not shown). Therefore, all results are presented as mRNA relative abundance to 16S. pGEM-T Easy plasmid clones of all target genes that were used as quantitative standards in real-time PCR were generated by Thwaites and co-workers (2004). TaqMan PCR reactions were performed using qPCR no-rox kit (Eurogentec, Southamptom, U.K.) in $25 \mu \mathrm{l}$ containing $5 \mu \mathrm{l}$ of cDNA template, $100 \mathrm{nM}$ forward and reverse primers, $300 \mathrm{nM}$ doublelabeled oligonucleotide probe, and $50 \mathrm{mM} \mathrm{MgCl}$. Primers and oligonucleotide probes, labeled with FAM and ELLE dyes at the 5' and 3', respectively, previously described by Thwaites and associates (2004), were used in this work. The following PCR amplification program was used: $10 \mathrm{~min}$ at $95^{\circ} \mathrm{C}$ and 40 cycles of $95^{\circ} \mathrm{C}(15 \mathrm{~s})$ and $60^{\circ} \mathrm{C}(1 \mathrm{~min})$. Reactions were run in a Rotor Gene 3000 detection system and analyzed by the rotor gene version 6.0 software. Amplification of four 10-fold dilutions of clones of all target genes was performed to obtain the related standards curves. Threshold detection parameters were adjusted automatically for the most part of the reactions; however, manual configuration was used in some cases. Duplicate samples of three independent experiments for each transcript were quantified and mean values were used to express mRNA abundance relative to $16 \mathrm{~S}$ RNA. Errors bars represent standard deviation. Each expression value was analyzed using homoscedastic and two-tailed Student's $t$ tests, and the null hypothesis: mean values are not significantly different from other expression values (with $P$ value $<0.05$ used).

\section{ACKNOWLEDGMENTS}

We thank T. Duarte for technical assistance and J. R. Albert for valuable discussions. I. Ortiz-Martín was supported by a Fellowship by Junta de 
Andalucía. This work was supported by a Project Grant (BIO2006-00673) from the Ministerio de Educación y Ciencia (Spain) to C. R. Beuzón, a Short-Term EMBO Fellowship awarded to I. Ortiz-Martín, travel funds granted by the Plan Propio of the University of Málaga, and funds granted by the U.K. Biotechnology and Biological Sciences Research Council (BBRSC) to J. Mansfield. The work was co-funded by Fondos Europeos de Desarrollo Regional (FEDER).

\section{LITERATURE CITED}

Alfano, J. R., and Collmer, A. 1997. The type III (Hrp) secretion pathway of plant pathogenic bacteria: trafficking harpins, Avr proteins, and death. J. Bacteriol. 179:5655-5662.

Arnold, D. L., Jackson, R. W., Fillingham, A. J., Goss, S. C., Taylor, J. D., Mansfield, J. W., and Vivian, A. 2001. Highly conserved sequences flank avirulence genes: isolation of novel avirulence genes from Pseudomonas syringae pv. pisi. Microbiology 147:1171-1182.

Beuzón, C. R., and Holden, D. W. 2001. Use of mixed infections with Salmonella strains to study virulence genes and their interactions in vivo. Microbes Infect. 3:1345-1352.

Beuzón, C. R., Unsworth, K. E., and Holden, D. W. 2001. In vivo genetic analysis indicates that PhoP-PhoQ and the Salmonella pathogenicity island 2 type III secretion system contribute independently to Salmonella enterica serovar Typhimurium virulence. Infect. Immun. 69:7254-7261.

Cesbron, S., Paulin, J. P., Tharaud, M., Barny, M. A., and Brisset, M. N. 2006. The alternative sigma factor HrpL negatively modulates the flagellar system in the phytopathogenic bacterium Erwinia amylovora under $h r p$-inducing conditions. FEMS (Fed. Eur. Microbiol. Soc.) Microbiol. Lett. 257:221-227.

Chatterjee, A., Cui, Y., Yang, H., Collmer, A., Alfano, J. R., and Chatterjee, A. K. 2003. GacA, the response regulator of a two-component system, acts as a master regulator in Pseudomonas syringae pv. tomato DC3000 by controlling regulatory RNA, transcriptional activators, and alternate sigma factors. Mol. Plant-Microbe Interact. 16:1106-1117.

Choi, K. H., Gaynor, J. B., White, K. G., Lopez, C., Bosio, C. M., KarkhoffSchweizer, R. R., and Schweizer, H. P. 2005. A Tn7-based broad-range bacterial cloning and expression system. Nat. Methods 2:443-448.

Cornelis, G. R., and Van Gijsegem, F. .2000. Assembly and function of type III secretory systems. Annu. Rev. Microbiol. 54:735-774.

Deng, W. L., and Huang, H. C. 1999. Cellular locations of Pseudomonas syringae pv. syringae $\mathrm{HrcC}$ and $\mathrm{HrcJ}$ proteins, required for harpin secretion via the type III pathway. J. Bacteriol. 181:2298-22301.

Ditta, G., Stanfield, S., Corbin, D., and Helinski, D. R. 1980. Broad host range DNA cloning system for gram-negative bacteria: construction of a gene bank of Rhizobium meliloti. Proc. Natl. Acad. Sci. U.S.A. 77:7347-7351.

Ferreira, A. O., Myers, C. R., Gordon, J. S., Martin, G. B., Vencato, M., Collmer, A., Wehling, M. D., Alfano, J. R., Moreno-Hagelsieb, G., Lamboy, W. F., DeClerck, G., Schneider, D. J., and Cartinhour, S. W. 2006. Whole-genome expression profiling defines the HrpL regulon of Pseudomonas syringae pv. tomato DC3000, allows de novo reconstruction of the Hrp cis clement, and identifies novel coregulated genes. Mol. Plant-Microbe Interact. 19:1167-1179.

Fouts, D. E., Abramovitch, R. B., Alfano, J. R., Baldo, A. M., Buell, C. R., Cartinhour, S., Chatterjee, A. K., D'Ascenzo, M., Gwinn, M. L., Lazarowitz, S. G., Lin, N. C., Martin, G. B., Rehm, A. H., Schneider, D. J., van Dijk, K., Tang, X., and Collmer, A. 2002. Genomewide identification of Pseudomonas syringae pv. tomato DC3000 promoters controlled by the HrpL alternative sigma factor. Proc. Natl. Acad. Sci. U.S.A. 99:2275-2280

Freter, R., Allweiss, B., O’Brien, P. C., Halstead, S. A., and Macsai, M. S. 1981. Role of chemotaxis in the association of motile bacteria with intestinal mucosa: in vitro studies. Infect. Immun. 34:241-249.

Grimm, C., Aufsatz, W., and Panopoulos, N. J. 1995. The hrpRS locus of Pseudomonas syringae pv. phaseolicola constitutes a complex regulatory unit. Mol. Microbiol. 15:155-165.

Guttman, D. S., Gropp, S. J., Morgan, R. L., and Wang, P. W. 2006. Diversifying selection drives the evolution of the type III secretion system pilus of Pseudomonas syringae. Mol. Biol. Evol. 23:2342-2354.

Haapalainen, M., van Gestel, K., Pirhonen, M., and Taira, S. 2009. Soluble plant cell signals induce the expression of the type III secretion system of Pseudomonas syringae and upregulate the production of pilus protein HrpA. Mol. Plant-Microbe Interact. 22:282-290.

Hanahan, D. 1983. Studies of transformation of Escherichia coli with plasmids. J. Mol. Biol. 166:557-580.

Hendrickson, E. L., Guevera, P., and Ausubel, F. M. 2000. The alternative sigma factor RpoN is required for hrp activity in Pseudomonas syringae pv. maculicola and acts at the level of hrpL transcription. J. Bacteriol. 182:3508-3516.
Hienonen, E., Roine, E., Romantschuk, M., and Taira, S. 2002. mRNA stability and the secretion signal of HrpA, a pilin secreted by the type III system in Pseudomonas syringae. Mol. Genet. Genomics 266:973-978.

Hienonen, E., Rantakari, A., Romantschuk, M., and Taira, S. 2004. The bacterial type III secretion system-associated pilin HrpA has an unusually long mRNA half-life. FEBS (Fed. Eur. Biochem. Soc.) Lett. 571:217-220.

Holmes, D. S., and Quigley, M. 1981. A rapid boiling method for the preparation of bacterial plasmids. Anal. Biochem. 114:193-19

Hutcheson, S. W., Bretz, J., Sussan, T., Jin, S., and Pak, K. 2001. Enhancer-binding proteins HrpR and HrpS interact to regulate hrp-encoded type III protein secretion in Pseudomonas syringae strains. J. Bacteriol. 183:5589-5598.

Huynh, T. V., Dahlbeck, D., and Staskawicz, B. J. 1989. Bacterial blight of soybean: regulation of a pathogen gene determining host cultivar specificity. Science 245:1374-1377.

Johnson, M. R., Wang, K., Smith, J. B., Heslin, M. J., and Diasio, R. B. 2000. Quantitation of dihydropyrimidine dehydrogenase expression by real-time reverse transcription polymerase chain reaction. Anal. Biochem. 278:175-184.

Lan, L., Deng, X., Zhou, J., and Tang, X. 2006. Genome-wide gene expression analysis of Pseudomonas syringae pv. tomato DC3000 reveals overlapping and distinct pathways regulated by $h r p L$ and $h r p R S$. Mol. Plant-Microbe Interact. 19:976-987.

Lee, J., Klusener, B., Tsiamis, G., Stevens, C., Neyt, C., Tampakaki, A. P., Panopoulos, N. J., Noller, J., Weiler, E. W., Cornelis, G. R., Mansfield, J. W., and Nurnberger, T. 2001. HrpZ (Psph) from the plant pathogen Pseudomonas syringae pv. phasolicola binds to lipid bilayers and forms an ion-conducting pore in vitro. Proc. Natl. Acad. Sci. U.S.A. 98:289-294.

Macho, A. P., Zumaquero, A., Ortiz-Martin, I., and Beuzón, C. R. 2007. Competitive index in mixed infections: a sensitive and accurate assay for the genetic analysis of Pseudomonas syringae-plant interactions. Mol. Plant Pathol. 8:437-450.

Mansfield, J., Jenner, C., Hockenhull, R., Bennett, M. A., and Stewart, R. 1994. Characterization of avrPphE, a gene for cultivar-specific avirulence from Pseudomonas syringae pv. phaseolicola which is physically linked to $\operatorname{hrp} Y$, a new hrp gene identified in the halo-blight bacterium. Mol. Plant-Microbe Interact. 7:726-739.

Ortiz-Martín, I., Macho, A. P., Lambersten, L., Ramos, C., and Beuzón, C.R. 2006. Suicide vectors for antibiotic marker exchange and rapid generation of multiple knockout mutants by allelic exchange in gramnegative bacteria. J. Microbiol. Methods. 67:395-407.

Ortiz-Martín, I., Thwaites, R., Mansfield, J. W., and Beuzón, C. R. 2010. Negative regulation of the Hrp type III secretion system in Pseudomonas syringae pv. phaseolicola. Mol. Plant-Microbe Interact. 23:682701.

Peñaloza-Vazquez, A., Preston, G. M., Collmer, A., and Bender, C. L. 2000. Regulatory interactions between the Hrp type III protein secretion system and coronatine biosynthesis in Pseudomonas syringae pv. tomato DC3000. Microbiology 146:2447-2456.

Preston, G., Deng, W. L., Huang, H. C., Collmer, A. 1998. Negative regulation of hrp genes in Pseudomonas syringae by HrpV. J. Bacteriol. 180:4532-4537.

Rahme, L. G., Mindrinos, M. N., and Panopoulos, N. J. 1992. Plant and environmental sensory signals control the expression of hrp genes in Pseudomonas syringae pv. phaseolicola. J. Bacteriol. 174:3499-3507.

Roine, E., Wei, W., Yuan, J., Nurmiaho-Lassila, E. L., Kalkkinen, N., Romantschuk, M., and He, S. Y. 1997. Hrp pilus: an hrp-dependent bacterial surface appendage produced by Pseudomonas syringae pv. tomato DC3000. Proc. Natl. Acad. Sci. U.S.A. 94:3459-3464.

Sambrook, J., Fritsch, E. F., and Maniatis, T. 2001. Molecular Cloning: A Laboratory Manual. Cold Spring Harbor Laboratory Press, Cold Spring Harbor, NY, U.S.A.

Schuster, M., and Grimm, C. 2000. Domain switching between HrpR and HrpS affects the regulatory function of the hybrid genes in Pseudomonas syringae pv. phaseolicola. Mol. Plant Pathol. 1:233-241.

Taira, S., Tuimala, J., Roine, E., Nurmiaho-Lassila, E. L., Savilahti, H., and Romantschuk, M. 1999. Mutational analysis of the Pseudomonas syringae pv. tomato hrpA gene encoding Hrp pilus subunit. Mol. Microbiol. 34:737-744

Taylor, R. K., Miller, V. L., Furlong, D. B., and Mekalanos, J. J. 1987. Use of $p h o A$ gene fusions to identify a pilus colonization factor coordinately regulated with cholera toxin. Proc. Natl. Acad. Sci. U.S.A. 84: 2833 2837.

Thwaites, R., Spanu, P. D., Panopoulos, N. J., Stevens, C., and Mansfield, J. W. 2004. Transcriptional regulation of components of the type III secretion system and effectors in Pseudomonas syringae pv. phaseolicola. Mol. Plant-Microbe Interact. 17:1250-1258.

Vencato, M., Tian, F., Alfano, J. R., Buell, C. R., Cartinhour, S., DeClerck, G. A., Guttman, D. S., Stavrinides, J., Joardar, V., Lindeberg, M., 
Bronstein, P. A., Mansfield, J. W., Myers, C. R., Collmer, A., and Schneider, D. J. 2006. Bioinformatics-enabled identification of the HrpL regulon and type III secretion system effector proteins of Pseudomonas syringae pv. phaseolicola 1448A. Mol. Plant-Microbe Interact. 19:1193-1206.

Wang, T., and Brown, M. J. 1999. mRNA quantification by real time TaqMan polymerase chain reaction: validation and comparison with RNase protection. Anal. Biochem. 269:198-201.

Wei, W., Plovanich-Jones, A., Deng, W. L., Jin, Q. L., Collmer, A., Huang, H. C., and He, S. Y. 2000. The gene coding for the Hrp pilus structural protein is required for type III secretion of Hrp and Avr proteins in Pseudomonas syringae pv. tomato. Proc. Natl. Acad. Sci. U.S.A. 97:2247-2252.

Willis, D. K., Hrabak, E. M., Rich, J. J., Barta, T. M., Lindow, S. E., and Panopoulos, N. J. 1990. Isolation and characterization of a Pseudomonas syringae pv. syringae Mutant deficient in lesion formation on bean. Mol. Plant-Microbe Interact. 3:149-156.

Xiao, F., Goodwin, S. M., Xiao, Y., Sun, Z., Baker, D., Tang, X., Jenks, M.
A., and Zhou, J. M. 2004. Arabidopsis CYP86A2 represses Pseudomonas syringae type III genes and is required for cuticle development. EMBO (Eur. Mol. Biol. Organ.) J. 23:2903-2913.

Xiao, Y., and Hutcheson, S. W. 1994. A single promoter sequence recognized by a newly identified alternate sigma factor directs expression of pathogenicity and host range determinants in Pseudomonas syringae. J. Bacteriol. 176:3089-3091.

Xiao, Y., Lu, Y., Heu, S., and Hutcheson, S. W. 1992. Organization and environmental regulation of the Pseudomonas syringae pv. syringae 61 hrp cluster. J. Bacteriol. 174:1734-1741.

Xiao, Y., Heu, S., Yi, J., Lu, Y., and Hutcheson, S. W. 1994. Identification of a putative alternate sigma factor and characterization of a multicomponent regulatory cascade controlling the expression of Pseudomonas syringae pv. syringae Pss61 hrp and hrmA genes. J. Bacteriol. 176:1025-1036.

Zipfel, C., Robatzek, S., Navarro, L., Oakeley, E. J., Jones, J. D., Felix, G., and Boller, T. 2004. Bacterial disease resistance in Arabidopsis through flagellin perception. Nature 428:764-767. 